University of Louisville

ThinkIR: The University of Louisville's Institutional Repository

Electronic Theses and Dissertations

1940

\title{
A housing project in Louisville : its social interpretation : a study of College Court.
}

Howard B. Hollenbeck 1916-1971

University of Louisville

Follow this and additional works at: https://ir.library.louisville.edu/etd

Part of the Community-Based Research Commons, and the Urban Studies and Planning Commons

\section{Recommended Citation}

Hollenbeck, Howard B. 1916-1971, "A housing project in Louisville : its social interpretation : a study of College Court." (1940). Electronic Theses and Dissertations. Paper 1792.

https://doi.org/10.18297/etd/1792

This Master's Thesis is brought to you for free and open access by ThinkIR: The University of Louisville's Institutional Repository. It has been accepted for inclusion in Electronic Theses and Dissertations by an authorized administrator of ThinkIR: The University of Louisville's Institutional Repository. This title appears here courtesy of the author, who has retained all other copyrights. For more information, please contact thinkir@louisville.edu. 
UNIVERSITY OF LOUISVILLE

A HOUSIWG PROJECT IN LOUISVILLE--ITS SOCIAL INTERPRETATION

A STUDY OF COLLEGE COURT

A Dissertation

Submitted to the Faculty

Of the Graduate School of the University of Louisville

In Partial Fulfillment of the

Requirements for the Degree

of Master of Science in Social Administration

Division of Social Administration

By

Howard B. Hollenbeck

1940 
NAME OF STUDENT: Howard B. Hollenbock

TITLE OF THESIS: A Housing Project In Louisvillo:

Its Social Interpretation;

A Study of College Court

APPROVED BY READING COMITTEE COMPOSED OF THE

FOLLOWING MEMBERS:

NAME OF DIRECTOR: Dr. Margaret $K$. strong

DATE: June 4, 1940 


\section{ACKMOMLEDGMMENT}

For assistance with this thesis, I owe thanks to many individuals. I wish especially to acknowlodge my gratitude to $\mathrm{Mr}$. Charles Walte for his assistanco and cooperation; to Mr. E. E. Pruitt for the use of his files and records from which some of this material was obtained; to Mr. Gardner F. Cook for his advice and guidance; to Dr. Charles Parrish for his advice and information; and to Miss Elizabeth Wils on for her understanding aid.

Fispeoial thanks are due Dr. Margaret $K$. Strong, without whose help and understanding guidance this thesis may not have been written. 
A HOUSING PROJECT IN LOUISVILLE--ITS SOCIAL INTERPRETATION A STUDY OF COLLEGE COURT 
TABLE OF CONTENTS

Page

INTRODUCTION

I. THE PLACE OF HOUSING IN THE GENERAL WELFARE PROGRAM . . . . . . . . . . . . . . 5

II. THE HISTORY OF HOUSING IN LOUISVILLE . . . . 21

III. COLLEGE COURT-A HISTORY AND INTERPRETATION . - 41

IV. GROUP LIFE AND LEISURE TTME WITHIN THE PROJECT. 66

CONCLUSIONS

98

BIBLIOGRAPHY 
INTRODUCTION 


\section{INTRODUCTION}

The general aim of the housing project is to provide housing for those who need it. The importance of providing housing for those who need it lies in 1 ts aid to physical, mental and moral health. The present nation-wide publio interest in housing is unpreoedented. Large housing projects have been and are being planned and built. Entire neighborhoods are being created with dwellings thit will last for generetions.

How will this widespread building activity affect the social life of the people to be housed? Certainly such projects are of value in providing opportunity for social contacts. From these social cont ots a democratic ideal may develop. The development of this democratic ideal might be noted as a secondary objective of the United States Housing Authority and the housing project.

This study has been undertaken in order to interpret the effect of the public housing development on the group life of its residents. Resulting information may enable public housing in Louisville, Kentucky, to benefit by the experiences of an older devol opment.

College Court, a housing project for Negroes, was built in Louisville, Kentucky, in 1937. On December 27 of that year the first tenant moved in. The $\$ 776,000$ project includes one hundred and twentyfive modern dwelling units. Two, three, four and five room apartments are provided. College Court represents a housing project to which at 
least a minimum of thought and effort had been given to incorporate in its plans facilities providing the residents with opportunities for recreation and social participation. The project is a small one ocmpared with nost housing developments in larger cities and with newly constructed projects in Louisville.

College Court has been studied by the writer because it is one of the first of two planned housing developments in Louisville, and because time and work capacity limitations made necessary the study of a small project. It was evident in addition that considerable effort had been made to meet the social and recreational needs of the residents in this partioular housing developmont.

Newly constructed developments in Louisville will be larger scale projects in which hundreds of families will dwell. Naturally the question of their participation in social, reoreational and group activities is a vital one. Does the housing of people together within one common housing development have any effect upon the social relationships and group life of these people? What are the possibilities for the development of community life within the projeot? Do similarity in dwelling units and a uniqueness in better and new living conditions bring about a spirit of neighborliness and a sense of "belonging"? Do sinilarity in income and former living conditions stimulate group life and make for more conoerted group and social action?

Does the comperative size of the housing project affect the possibility of group and community life in any way? How large a part does leadership play in the development of group activities? Are the 
present recreational facilities provided in the project adequate for the carrying on of a social activities program? And finally, what is the effect of the group life on the lives of the residents?

The writer has found it neoessary to present a brief account of housing in Louisville, Kentucky, as well as the place of such a program in general welfare work. This serves as a background for the actual social interpretation of College Court.

Cooperation wes willingly given by the Louisvillo Housing Commission. Records and data regarding project construction in the city were provided at the Commission office. College Court itself was next approeched through its resident manager. The managenent's files and data collected over a period of two years served as a basis for further research. The Municipal College for Negroes aided to same extent through its sociology department.

Contacts and acquaintances with College Court residents were made possible through the resident manager. Questionnaires were distributed to an adequate cross-section of tenants. Interviews with many residents followed the collection of the questionnaires. Club meetings were visited and activity programs attended. Minutes and records of the various clubs served as aids in activity analysis. 
I. THE PLACE OF HOUSIUG IN A GENERAL WELFARE PROGRAM 
THE PLACE OF HOUSING IN A GEHERAL MELFARE PROGRAM

Housing as a problem of human welfare is as old as the human race itself. Although we have little idea of the manner of construction which was employed by the primitive races of the world, we are not wholly ignorant of the fact that from time to time the housing of the lower economic classes claimed the attention of the rulers. In this connection we might recall that "Egyptian hieroglyphio inscriptions dating as far back as 4000 B.C. record a sit-dom strike of the workers who participated in the building of the pyramids. The result was the first attempt to construct a model tow in exchange for a waterproof tomb so essential to the health of the immortal souls of the Pharaohs." The housing problem is essentially that of finding the best means to make safe, wholesome and sanitary dwellings available to all families, irrespective of income. Since comnercial enterprise can be relied upon to provide dwellings of adequate standards for that fraction of the population whioh oan afford to pay 5,000 or more for house property or a rent of $\$ 40$ or more a month for an apartment, a public housing policy is concerned primarily in making wholesome housing available to families with smill incomes -- especially to unskilled and semi-skilled labor.

Like the proverbial skeleton in the family closet, our

1.Aronovici, Carol, Housing the Masses, Nev York, John Wiley \& Son, 1939, Introduction, p. xi. 
overorowded tenements stand to remind American communities of their sins. We build marble halls for our city fathers, and on their steps receive foreign visitors, who exclaim about our beautiful cities. Tucked away in the very shadows of these halls may be found ugly tenements or shacks unfit for human habitation, yet serving as homes for generation after generation of American citizens and their offspring. We proudly boest of our skyscrapers. Yet, hidden behind them, as if ashamed of their time-worn facades, shabby old houses huddle together, propping each other up in their weakness. We build many mansions, but permit the slums to remain.

Students of the existing social order are realizing increasingly the importance of housing to sociel progress. The surveys of crime comissions, departrients of health and the studies of experts in juvenile delinquenoy, probationary work and family welfare all point to a close correlation between housing and health, safety and the social behavior of the community.

The child is always the first and easy victim of a bad homo environment. Sensitive to impressions, he forms during those early years spent in ugly physical surroundings, attitudes and habits which are usually modified only with the greatest difficulty - and often through intense suffering. In the report of the Wickersham Crime Commission, we find the terms "delinquency areas" and "slum areas" used interchangeably. The Ner York Crime Commission submits the following testimony: "Urban sooiologists claim that juvenile delinquency and crime, while not completely confined to any given areas 
or sootal olass, arise primarily in certain transition areas of poor 2 housing popularly oalled "slums". Slum districts have not only been breoders of a good deal of crime, but have been noted for their high rate of infant mortality. In 1925 the United States Children's Bureau made an exhaustive study of the causal factors in infant mortality. It examined conditions in 8 cities, where widely different housing conditions prevailed. It discovered that, where families lived less than one person in a room, the infant death rate was 52.1 per thousand, as compared with 94.9 por thousand in families in whioh the average wa between one and two persons per rocm, and 135.7 per thousand in families in which the average rose to two or more persons per room.

Slum districts are also conducive to high morbidity. It has been pessimistically stated that there is only one thing more costly to the worker than burial, and that is sickness. Teachers in slum areas are only too aware of the effect of ill-ventilated, overcrowded, noisy sleeping quarters on the health of school children. Visiting nurses know the easy susceptibility of these children to illness of all kinds. They have in general little reserve strength and resistance against the various illnesses and communicable diseases to which their hane environment exposes them.

As with delinquency or infant mortality, it is difficult to measure in exact terms the degree to which long hours spent in dark,

\footnotetext{
2. Report of the Nev York State Crime Commission, 1930, p. 114. 3. Causal Factors in Infant Mortality, Publication No. 142, U. S. Children's Bureau, 1925.
} 
damp roons contribute to the high rate of siokness, tuberoulosis and other diseases common among slum dwellers. It is an old adage that "where the sun does not enter in, the doctor does."

In the congested portions of our cities, large and small, we establish clinics and all manner of public and private welfare agencies, and yet we maintain housing conditions which breed disease far more rapidly than it can be wiped out. Block studies in the past have invariably disclosed the high rates of siokness and crime prevailing in bad housing areas. When they also include the cost to the commuity in dollars and cents of these social evils, we might be able to arouse our friends the "Taxpayer" and the "Rentpayer" to action.

The community is thus paying dearly for its slums and insanitary homes for the workers, in delinquency and crime, in sickness and death, and in terms of all the worthwhile values in social life.

The proponent of individual responsibility sees in the plight of the slum dweller evidence only of personal failure. He takes the position that those who live in broken-down, insanitary, old houses are probably there because they choose to be or because they do not know any better. He believes in placing the whole burden of the risk involved in the occupation of inadequate dwellings upon the individual wage-earner. He leaves the worker alone to meet a great social hazard over which the individual tenant can exert little or no control. The tenant can only adjust the neods of his family to a sub-standard house. He cannot replace the house with a better one.

Here and there through the years there have been certain individuals who have shown themselves sensitive to the implications of 
a bad home environment. As philanthropists they have tried to do something about conditions, but the problem had now been put on a more scientific and practical basis. Social welfare work is becoming scientific, and social service a career and a profession. Neighborhood settlements are conducted with a greater degree of efficiency; health centers and hospitals have become a very important part of city governments. In New York City one of the symbols of an awakened social conscience about slum housing was the establishment of a Tenement House Department, created in the early part of this century for the sole purpose of enforcing the Tenement House Law -- then considered a drastic one - and of compelling a responsibility of operation upon the owners of the old-law tenement houses which had been built in earlier years. These were great things in this day. Tremendous strides have been taken since then toward the acceptance of the social responsibility for conditions created by the slum, but so far they have resulted only in alleviation and not in the elinination of the deepseated evils.

Until recently the problem has been recognized ohiefly by

\footnotetext{
Post, L. W., The Challenge of Housing, New York, Farrar \& Rinehart, 1938.

"It would be wrong to give the impression that the efforts of the social ageneies or the oity government itself have been useless, but it is certain that the results have not justified the costs. At the beginning of any reform human beings seem incapable of tackling an original social problem by going to its roots. Had society in Jacob Riis's time considered that the slums wore actually uneconomic and unprofitable, or had it came to the conclusion that their elimination would have created profits, we would have no sluns today. But so long as people felt that the battle against the slum was a moral one, to be led by the social reformer, society as a whole remeined indifferent."
} 
the social welfare worker and the philanthropist. The economics involved in the clearance of the sluns has not yet been properly presented. Any progress that has been made has boen in spite of the dominant econamio elements in the cities, not with their help or consent. Human need has been the only weapon used to gain support for whatever progressive action has been taken. Persons like Lillian Wald, Jane Addams, Mary Simkhoriteh have taken the lead. Because they had no stronger weapons, the history of New York's attempts to meet the ever-growing menace of the slum is largely a story of failure and futility and yet New York has accomplished more than any other city in this country.

We may rail about the slums of our great cities, but unless we do something to reduce the cost of building decent houses for the workers and to lower the rents of the houses, or unless we greatly increase the income of the average working class family, we will make little headway toward the solution of the housing problem. Edith Elmer Wood, author of Recent Trends in American Housing, and one of the foremost authorities on housing in the United States, ws right when she said:

"The orux of the housing problem is economic. Under the ordinary laws of supply and domand, it is insoluble. In our modern industrial civilization, the distribution of income is such that a substantial portion of the population cannot pay a commercial rent, much less a commercial purchase price, for a home fulfilling the minimum health and decency requirements." 5

5ood, Edith Elmor, Recont Trends in American Housing, Now York, Macmillan Co., 1931, p.I. 
At all times, and in every part of the country, there has been a deadlock between the capacity of the average wage-earner to pay an economic rent for a now home and the speculative builder's failure to oonstruct dwellings to meet workingmen's needs. Private enterprise finds it not an advantage, nor a responsibility, to enter non-campetitive fields of home building. The speculative builder is interested neither in mas production nor in large-scale planning. He is concerned primarily with a quick return on his investment.

The builder is not elone responsible for this deadlock. He is froquently forcod to pay a high price for land, and can get a return on his investment only by erecting high-rent epartments.

Under private landlordism no sure control of site value is possible. Property owners are constantly engaged in pressing for such changes in zoning ordinances as might yield them a higher immediate revenue. They are constantly found in opposition to city plans which have the health of the people rather than the wealth of industry and business as their basic consideration.

Catherine Bauer in her book, "Modern Housing", expresses some doubt as to the possibility of fitting a real housing program into our present economic system. Long ago and from another point of riew, Fredrich Engels, Karl Marx's co-writer, dismissed the idea as nothing more nor less than a trick on the part of capitalism to maintain low wages.

Miss Bauer bases her doubts on the general theory that sinoe there is no profit in properly housing most of the people in this 
country, and since housing seems to be tied into the profit system, we cannot have good housing until we get rid of the profit system.

Engels believed that if you should give poor people good housing you would be taking away one of the most potent reasons for paying better wages. His objections sprang from two of his basic conoopts. He felt that anything as socialistic as public housing could not possibly exist within a capitalistic structure, and to acknowledge that it could, would be the same as denying one of the chief premises of socialism. He was also avare that if capitalism could solve the problem of housing the poor it would undoubtedly delay the revolution.

Housing is not only an economic question, not only a question of supply and demand and of furnishing a sufficient nunber of homes, but one in which the kind of home is of vital importance.

From early colonial times to the present, building practices which have rendered homes grossly insanitary or unsafe have in increasing degree been curbed by legislation. The era of comprehensive, co-ordinated housing laws, hovever, practically began with the New York Tenement House Act of 1901. Its principles were extended to the rest of the country through the formation, in 1910, of the National Housing Association and the publication, in 1914, of Lawrence Veiller's "A Model Housing Law".

The majority of States still lack effective housing legislation. A large percentage of building and housing laws are antiquated in the sense that they fail to facilitate the use 
of new materials and construction methods. Many of the smaller cities lack building laws. "The Real Property Inventory, conducted in 64 cities by the United States Depertment of Commeroe in 1934, found 16.8 per cent of occupied dwelling units crowded, 13.5 per cent lacking private indoor toilets, 20.2 lacking bathtubs or showers, 8.1 per cent without modern lighting, and 5 per cent without running water." ${ }^{6}$ By these standards at least a fifth of our urban population dwell under unwholesome conditions; but experienced soial workers are satisfied that fully a third of our population lacks adequate housing.

Housing legislation end competent administration are essential parts of a well-rounded housing policy, but in themselves will not provide a solution of the housing problem. In the main the best enforcement of existing laws is obteined in cities which have private housing associations that continuously inspect existing housing, report violations of the law to the appropriate department of the municipal government, and back publio officials in the vigorous enforcement of existing legislation while working continuously for its improvement.

Beginning with the pioneer efforts of the Association for Improving the Conditions of the Poor in New York City, in the middle of the last century, attempts have increasingly been made to contribute to the solution of the housing problem by the construction of model

6. Sooial Work Year Book, Russell Sage Foundation, 1939, p. 170. 
tenements, or model communities, financed by private philanthropic capital. Although the percentage of the total volume of dwelling construotion ascribable to such means has always been very low, the movement has had definite importance because of the contributions which it has made to researoh on family needs and family standards, to improved design and construction, and, in the present century, to commity planning with reference to the recreational, cultural, esthetic and social needs of the population thus housed.

Some governmental aid - but very little -. was avilable for the encouragement of improved housing of wage-earners prior to the third decade of the present century. Prior to the World War our federal government had developed no systematic undertaking for the direct construction and operation of dwellings for wage-earners other then its own employees, or dependents. Then, to provide homes for our war workers, the War and Navy Depertments, and later the United Stetes Housing Corporation and Fmergency Fleet Corporation built many industrial villages. Though the venture was temporary and the houses and villages subsequently disposed of (except for navy yards), experience had been developed in large-scale public housing.

In the period of extreme economic depression of the early thirties, three factors -- the developing housing shortage, the deterioration of old dwellings through the virtul cessation of repairs, and the need of finding employment for labor - led to the revival of publio housing as an emergency moasure. Its beginnings 
took the form of federal first mortgage loans to approved limiteddividend housing companies under the Reconstruction Finance Corporation established by the Emergency Relief and Construction Act of 1932. Knickerbocker Village in New York City was the only housing project to receive such a loan, for in the following year the Publio Works Administration was established under the National Industrial Recovery Act and applioations for housing loans were thereafter transferred to its Housing Division. Altogether seven projecto received its aid.

The next stage in the development of public housing was entered late in 1933 when the Housing Division of the Public Works Adninistration undertook to acquire land, whether in slums to be cleared or on the outskirts of the cities, and to build directly with federal funds, though with the advice of state or local housing authorities or citizens' committees.

Altogether 51 projects in 36 cities in the United States and two in its insular possessions were under active construction by September 7, 1937, at a totel cost of $\$ 134,000,000$. This represented accomodations for 21,800 femilies.

Within the 51 projects the population tends to represent families that have been in serious neod of wholescme accomodation. The clientele is one which could not afford now housing in the absence of the government's program, since privete enterprise would not find it profitable to build for them. The methods and standerds of this branch of public housing have, however, been such as to 
prevent the rehousing of the very poorest, or those who have previously endured the most wretched housing of the community.

After several years of intensive effort to establish a permanent federal policy for slum clearance and low-cost housing the United States Housing Act was pessed by Congress August 21, 1937. Its purpose is to establish a long-term permanent program of federal aid to State and local governments, for slum clearance and housing for families of lowest income. A permanent United States Housing Authority under the direction of the Administrator was created within the Department of the Interior. The Authority is now under the Federal Worke Agency. Loans may be made to local public housing agencies and are limited to 90 per cent of the cost of the projeots. Interest on loans under the law is to be not less than the cost of the money to the Federal Government, plus one and one half per cent, and must be repaid in not more than 60 years. Bonds guaranteed by the United States may be issued by the Authority to raise funds for these loans: one hundred million dollars in 1937, two hundred million in 1938, and two hundred million on and after July 1, 1939. Such bonds and their interest are to be repaid fram the proceeds of loans on the housing projects.

Two kinds of federal grants are made possible under the Act in addition to the laans. First, annual grants limited to amounts necessary to achieve low rents and to run for not more than 60 years; and second, capital grants as an alternative, which are limitod to 25 per cont of the cost of the project, plus an additional 15 per 
cent which the President may alloote from relief funds for the payment of labor. The dwellings constructed are in all cases to bo avilable only to lowest inoome families, whose income must be less than five times the rentel including utilities, or six times the rental in case of families with three or more children. In all cases where grants are made the local government must contribute at least 20 per cent of the federal annual contribution, either in cash, tax remissions, or exemptions. In case of capital grants the local government must contribute at least 20 per cent of the project's cost in cash, land, community facilities, services, tax remissions, or exemptions. Grants are possible only in projects in which there is slum clearence, and housing must be provided in the new project equal in number to the acomodations demolished.

Thus $\$ 500,000,000$ has been made available by the Act for lowcost housing. The present status of the United States Housing Authority is that of research, stimulation of appropriate organization of local housing authorities, and allocation of funds for approved projects.

Public housing in this country is largely an outgrowth of mothods of combatting the econamic depression of the early thirties. It has grown even though it started under these not too favorable ciroumstances. Similarly, public responsibility for relief and welfare policies, with the exception of institutional care for various special groups, was recognized in a new way at about the same time and as a result of the same economic forces. Recently 
same astonishment has been expressed, perhaps not entirely warranted, that public housing and public welfare activities heve had littlo in common and, in many respects, seem to have been drifting further apert. About the middle of 1938, however, housing officials began to re-exanine their orthodox attitude toward relief families. For some time the consensus of opinion among housing officials had boen that the inmediate objective of low-rent housing sa the low-income, but more or less steadily employed wege-earner. They had no serious objections to housing families on relief, but felt that the responsibility lay with the relief officials to provide sufficient funds so that these families could pay the rent set for the low-income wageearner. During the last few months, however, housing experts have begun to realize that the problem is not quite so simple as that. The U. S. Housing Authority now considers relief families as one of the markets for the housing it finances.

On the other hand, up until very recently, public relief officials generally peid very little attention to public housing. Some of them have experimented with direct oonstruction, with Work Projects Administration labor, of housing for families on their own rolls. Almost without exception these experiments have been failures. Also in the early thirties many public relief agenoies had no long-term policy with respect to the payment of rent. Many paid rent only as a last resort to prevent evictions. Gradualiy this has been changed until now a considerable proportion of the public agencies pay some amount for rental as part of the regular 
family budget.

The administretions of public housing and of public welfare aotivities touch at other points. Those just cited, however, indicate the need for some common ground and same means of approaching the problems that are common to the two groups. During 1938 the governing boards of both the American Public Welfare Association and the Wational Assooiation of Housing Officials approved the establishment of a joint Committee on Housing and Welfare. The Public Administration Clearing House has offered to sponsor a special conference of housing and relief officials to discuss at length their comnon problems and relationships. With the active cooperation of these agencies and their constituent members, there is reason to believe that same progress may be made in outlining administrative policies that will make public action more effective both in housing and in welfare. American communities must accept the challenge of the bad conditions of housing which extend over the length and breadth of the continent. We have new forms of group life and new social responsibilities. The wage-earner of the lower income group today is continuously hovering between public assistance and independence. The hazard of bed housing is one over which he as an individual can exert little control. Fith the failure of private enterprise to meet the housing needs of the majority of the population, the community pays the heavy toll of disease, death and crime, due to indecent dwelling areas. 
II. THE HISTORY OF HOUSING IN LOUISVILIE 
THE HISTORY OF HOUSING IN LOUISVILIE

Why do we have slum and blighted areas in Louisville?

In general our slums ere a result of a number of situations and faotors. The exit of families from once well established residential areas. into less orowded quarters in outlying parts of the city has left its mark on Louisvilie's housing. The manner in which cities grow has materially changed since the advent of rapid and economical automobile transportation. Whereas the limits of close development were formerly fixed by the length of time it took to reach the central business district by electric street railway, these limits are now extended tremendously since the use of the autamobile has become so widespread.

Practically all municipalities are experiencing a loss in population in the close-in, older parts of the oity. Studies indicate that in Louisville between 1920 and 1930 the area bounded by the River, Shelby Street, Oak Street, and 14th Street hes experienced a loss of 10,000 population or more than $14 \%$ in a ten year period. The population in the same area was practically stationary between the years 1910 and 1920, indicating that decentralization has only recently begun in Louisville.

Another factor contributing to slum conditions is the entranceof low-income groups into vacancies made by the exit of families able to pay higher rentals. The removal of all families able to afford 
higher rentals, and complete occupancy by lar-income groups whose low rents make repairs by landlords unprofitable adds its contribution to blighted areas. Because of his oomparatively low economic status and other reasons, many Negroes are forced to live in the so-called blighted districts, the land of which is valued more than that on which the nevrer residenoe sections are developed. Here taxes are high, rents are 1 ow and consequently there is every incentive to the property owner to avoid spending any money for improvements so long as the tenants are willing to put up with the conditions. There are further main factors contributing to the establishment of slum and blighted areas. One is increased traffic in areas lying close to our downtown business sections where our principal slums are located. Two more factors are the age and obsolescence of buildings, and the intrusion of industry and business incompatible to residential areas.

As far back as 1909, steps tfere taken in Louisville to remedy poor housing conditions. The Louisville Tenement House Commission was created as a result of the need of tenement house reform, as indicated by investigations undertaken in the auturn of 1908 by a joint comittee composed of members of the Civias Comittee of the Woman's Club and Advisory Board of the Associated Charities.

The members of this joint comittee ascertained from the Juvenile Court, the Soojal Settlement, the Colored Hission, the Health Office, and other sources the locations of cases of bad housing. They visited these locations and many others, making 
partial records of what they saw and securing piotures displaying some of the conditions as they found them. They also obtained, through the aid of various city depertments, some idea of the city water supply and sewerage facilities. They further investigated laws or ordinances that might apply to tenement or housing conditions. In January, 1909, the Woman's Club brought Miss Emily Dinwiddie, Secretary of the Tenement House Commissi on of the New York Charity Organization Society, to lecture upon the housing problem. Miss Dinwiddie spent two days in visiting some of the tenement districts, and the facts and pictures gathered by the committee were used by her in the lectures delivered at the time of her visit. The serious conditions found, together with the impossibility of reform under the inadequate city laws upon the subject, presented a mumicipal problem that awakened much interest. It was realized that Louisville had reached a point in its growth where preventive moasures were imperative in order to avoid conditions that render the tenements of some cities an almost hopeless problem. When the matter was brought to the attention of Mayor Grinstead he agreed to recommend to the General Council the oreation and appointment of a Tenement House Commission to investigate conditions and recommend remedies for the ovils found.

The result was that an ordinance was passed by the General Council and approved on February 16th, 1909, directing and authorizing the Mayor to appoint a Tenement House Commission for the purpose of investigating and reporting upon tenenent conditions. This ordinanoe 
carried an appropriation to the Commission of $\$ 500$, which appropriation was afterwards increased to $\$ 1,500$ to carry on the work. The Commission decided to obtain the advice of an expert and the services of Mr. Charles B. Ball, Chief Sanitary Inspector of Chicago, were obtained. He made a visit to this city, completed a thorough preliminary investigation of the field, and advised the Commission to employ a professional investigator to make a house-tohouse examination in the tenement districts and prepare data for a repart, according to the most approved and scientific methods. Accordingly, the Commission omployed Miss Janet E. Kemp, a professional investigator, and upon the 15th day of April, 1909, she entered upon her work.

Of the 44,912 families in Louisville, according to the 1900 census, a little fewer than two-thirds lived in separate houses, 7

a little over one-third in tenements and apartment houses.

Unlike many of the large eities, Louisville's tenements were not found in one or two districts, but seemed to be scattered over a very large area of the city, somewhat more thickly in the heart of the city. They were also found in groups of a fow blocks in the more outlying districts, in the alleys and small side-streets, and in isolated cases surrounded by one-family houses. The problems brought out in the study of the districts chosen were substantially

7. In same cities a tenement is defined as a house oocupied by three or more families; in others the definition includes all houses occupied by more than one family. 
the for all tenement neighborhoods of the city.

The investigation conducted by the Tenement House Comrission covered two hundred and twenty-eight houses in six districts. In addition to these six districts fourteon special studies were also made of individual tenements in different sections of the city. These districts were selected not as being necessarily the worst sections that could be found, but as being representative of the types of defective housing that were most prevalent in Louisville. It was not the purpose of the investigation merely to make sensational discoveries and present them in lurid language, but rather to give an impartial and uncolored statement of conditions found in sections which were recognized as offering typical examples of the housing conditions which Louisville provides for large numbers of its poorer citizens.

A study such as this, conducted in 1909, does not bring ono in contact with the aristocracy of labor, the specialized and well paid mechanic or artizan who can afford to surround himself with all necessary comforts and conveniences of life. An investigation of this kind is made in behalf of the weaker elements of the conmunity, the poorly paid, unskilled luborer, the newly arrived immigrant, and all of those who, by reason of inability to pay higher rentals, by the necessity for living near their work, or for the sake of the companionship of those of their own tongue and race, are forced to live in the more congested sections. These hove not the political influence or the capacity for concerted action wich would enable 
them to secure for themselves the reforms and changes that are needed to make their enviroment healthful and attractive. It is only as the community is actually aroused to the need for such action that the ovils from which they suffer will find a remedy.

The Tenement House Commission concluded its report in 1909 with the statement, "We would now summon all good citizens to the further task, the harder and never-ending task, of helping to make things right for everybody by wise legislation and by that eternal watchfulness which is the price of safety."

There have been publio-spirited oitizens in Louisvillo interested in better housing. Barly efforts to secure regulatory legislation resulted in the Kentucky State Tenement House Law for First Class Cities, 1910, a nadvanced pioce of legislation at that deto. It ws unfortunately repealed in 1922.

By 1910 the building trade in Louisville had reached significant proportions. The total value of building permits issued, including plumbing, electrio light and wiring, the erection of street electric signs and the installation of elevators, amounted to $\$ 4,665,549$.

An interesting comparison in the number of frame dwellings orected and their cost my be had by taking the figures for the fiscal years ending in 1906, 1909 and 1911.

\footnotetext{
8. Report of the Tenement House Commission of Louisville, 1909, p. 78. $9 \cdot$ Real Property Survey and Low Income Housing Survey of Louisvilie, Ky ., 1938-39, p. 16 .
} 


\begin{tabular}{lcc} 
Year & Number of Frame Dwellings Erected & Cost \\
\cline { 2 - 3 } $1905-06$ & 1,015 & $\$ 1,295,859$ \\
$1908-09$ & 770 & $1,030,687$ \\
$1910-11$ & 548 & $1,090,428$
\end{tabular}

It may be seen that the number of frame dwellings erected had decreased to approximately one-helf the 1905-06 figure during the five-yeer period, while the cost showed oomparatively little fluctuation. The decrease in the number of frame dwellings erected may be attributed to the fact that brick construction was becoming popular.

The fact that 548 frame dwellings were erected in 1911 at a cost within approximately two hundred thousand dollars of the cost figure for 1,015 dwellings erocted in 1906 is also pertinent. This comparison shows that a better type of frame dwelling was boing built. 10

It may bo interesting to examine the following chart propared from records of the City Building Inspector showing the total value of building permits between 1913 and 1938. It should be emphasized that these figures include only construction within the corporate limits of the city, no information being available for the county.

The graph indioating total building sinoe 1913 shors a rapid increase after the World War to a maximum in 1925 of about $\$ 30,000,000$. Since that time with the single exception of 1927, when non-residential building greatest, there has been a rapid and fairly uniform decrease to the depression period of little activity botween 1932 and 1935. The minor orest shown in 1936 was the result of the two 10. Ibid., p. 24. 
AII BUILDING PERMITS IN LOUISVILLE, 1913 - 1938

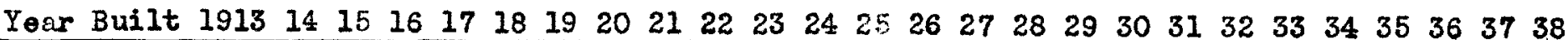

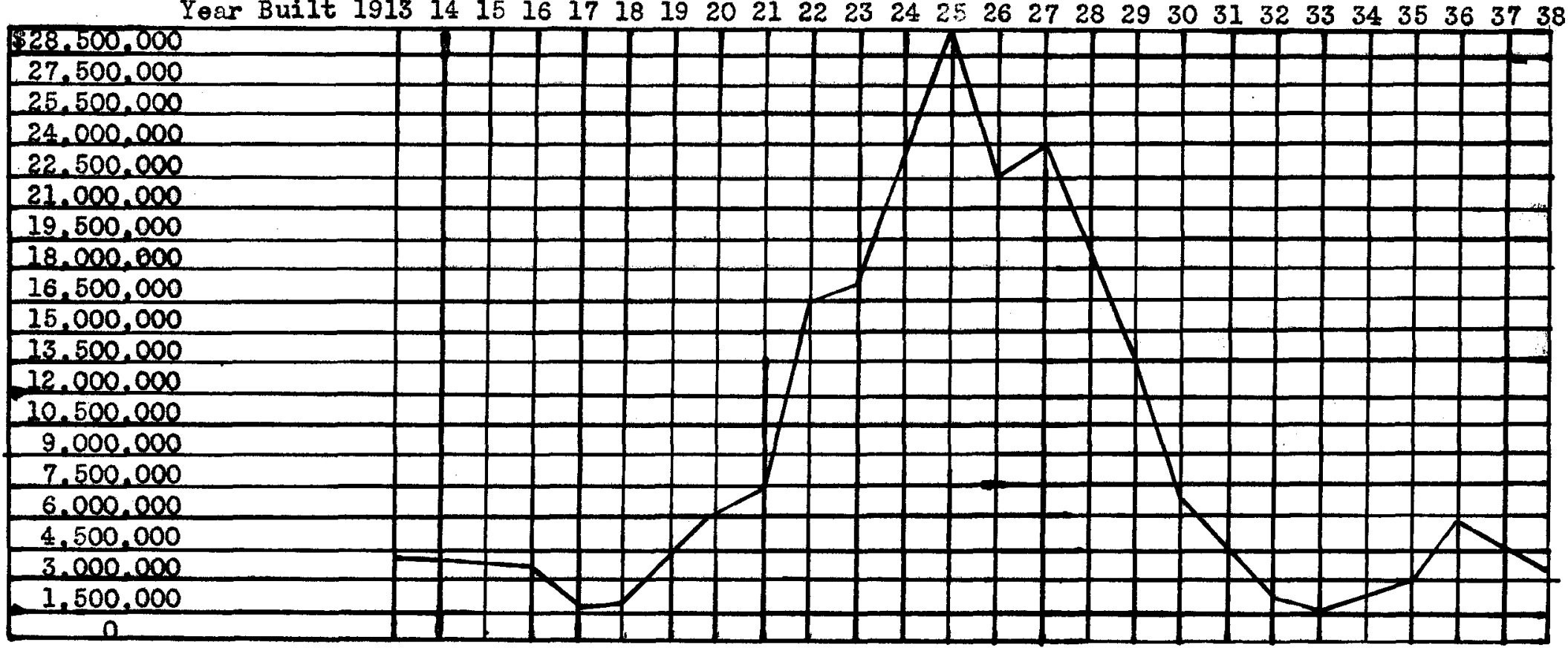

Source:- Office of Building Inspector, Loulsville, Ky. 
Public Works Administration Housing Projeots, La Salle Place and College Court. Residential construction increased rapidly between 1921 and 1925, after which a decline set in to the extremely low obb of the depression years. Non-residential building has been muoh more irregular. It reached its peak in 1927, two years later than residential building, and while the decline since that date has been rapid, it has suffered less than residential construction. Comparison of residential building during the pest ten years with that prior to 1929 indicates that Louisville is failing to provide sufficient new structures within the corporate limits and that new residential construction is advancing in the county area adjacent to Louisville. There is at present little replacement of obsolete buildings with new residences.

A study of the noed for housing in Louisville reveals the following facts.

Population

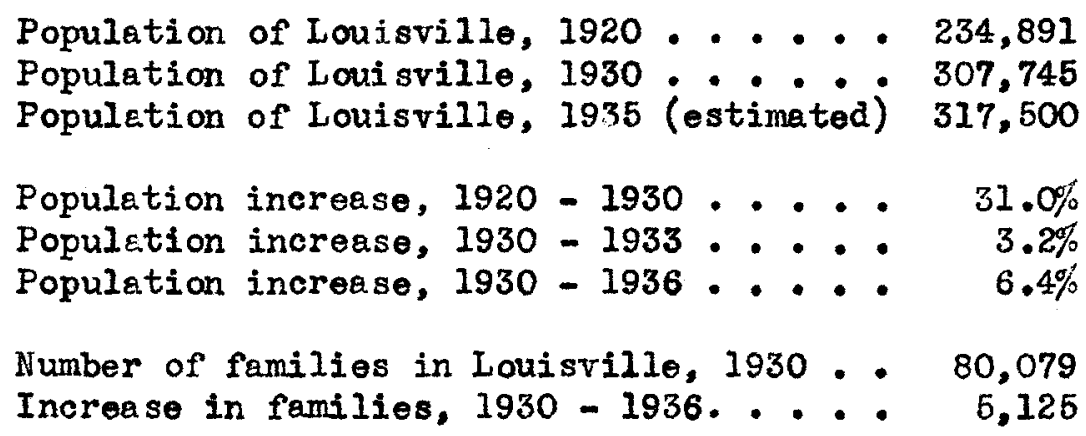

Ii. Statistics from U.S. Bureau of the Consus. 
Housing

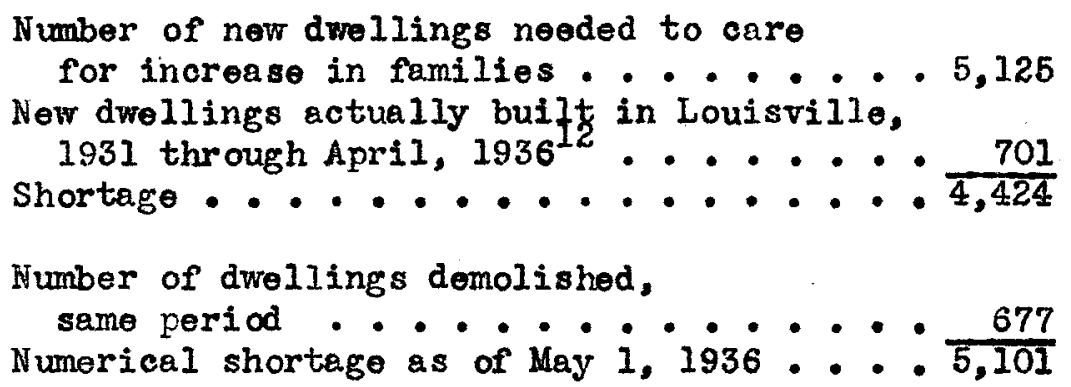

With regard to quantity, then, it would appear that a very real housing shortage existed in Louisville in 1936.

We learn a number of important items from the Louisville 13

Real Property Inventory which we may compare with the average of

the 64 cities where Real Property Inventories had been carried out by the Department of Commerce using the same schedules and methods which were subsequently used in Louisville. The best record of any of the 64 cities in each respect will also be shown.

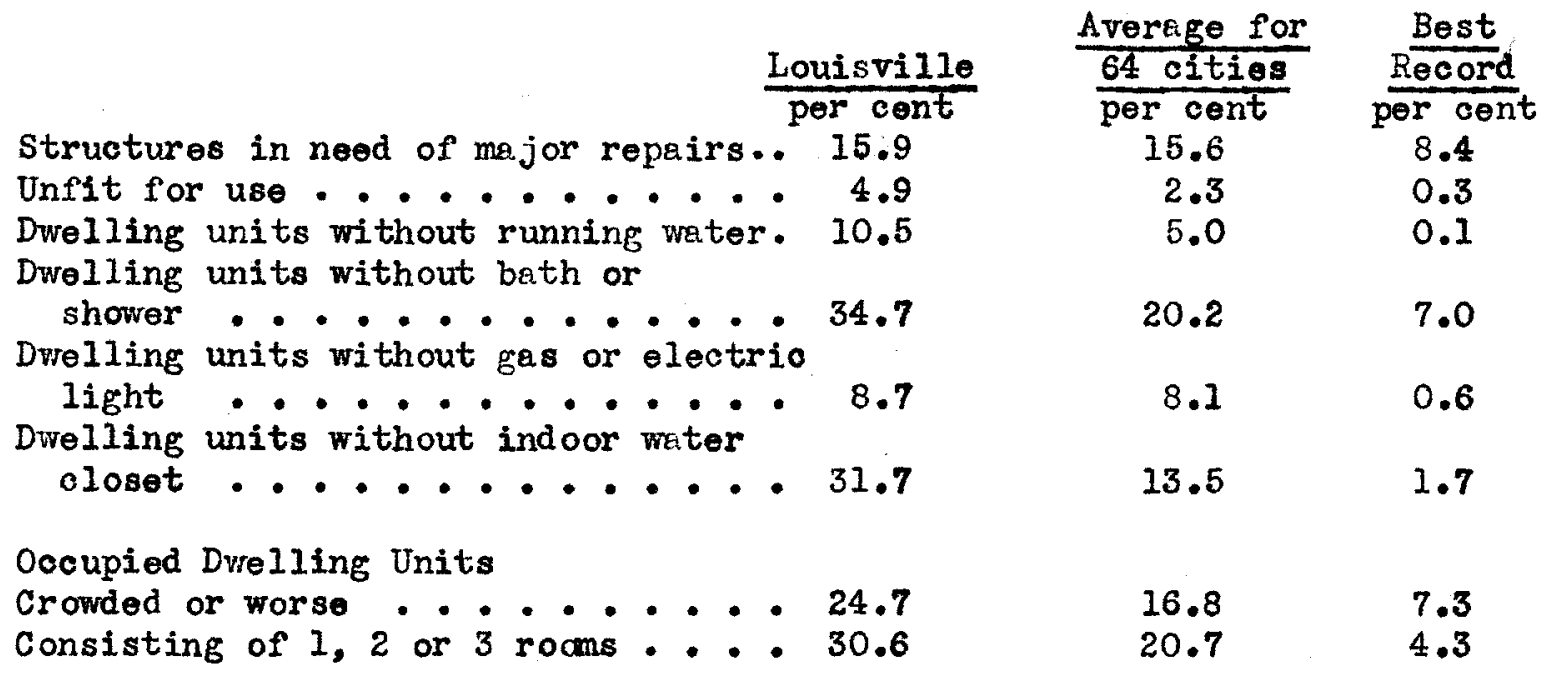

12 . Report of the Louisville Housing Advisory Committee, May 28, 1936. 13. Real Property Inventory of 1934, City Flanning and Zoning Commission, Louisvillo, Ky,, Detober, 1936 . 
Structures over 40 years old ..... $31.3 \quad 16.7$

$\frac{\text { Louisville }}{\text { per cent }} \frac{\text { Average for }}{\frac{64 \text { cities }}{\text { per cent }}}$

Rentel units under \$15 per month . . $47.6 \quad 20.6$

Hood construction........... 69.3

Single family houses ......... 60.3

Since the average housing standards of the 64 cities are

far from satisfactory, the conclusion is that Louisvillo has a very

considerable emount of 6 ub-standard housing which needs to be

replaced. Louisville's more than average share of older houses

accounts for some of her worn-out housing, but there is no necessary correlation. Four of the eight cities in the column of best records have substantially higher percentages of old houses than Louisville.

The City Planning and Zoning Comnission made a study of living conditions in Negro slum areas in 1931. The survey covered 165 blocks throughout the city. Such extensive investigations led to the conclusion that it was impossible to replace the dilepidated living quarters in congested districts with new housing by the use of private capital alone even when the present low cost of land and construction is taken into consideration.

Health regulations now in effect such as the Housing Law, Building Code, and Zoning Ordinance will largely prevent the future creation of such deplorable conditions as now exist in the Negro sections. Alley dwollings may no longer be built, the density of population is subject to close supervision and sufficient open spaces must be preserved around dwelling to insure adoquate ventilation.

Conditions that heve been brought about during the course 
of many years cannot be remedied in a short time. However, the whole question of housing began to receive more public attention than ever before, and various influences went to work to devise ways and means for bettering the conditions.

The City Planning and Zoning Commission's study of living conditions in Negro slum areas in 1931 (to be discussed in another chapter) resulted in the formation of the Citizens' Housing Committee. Later the City Planning Committee of the Boerd of Trade was appointed, and the three worked together.

Large-scale limited dividend operations with Federal loans were the first objective. Louisville was among the early applicants for loans from the Housing Division (September, 1933) for two white and two Negro slum clearance projects. The projects, as submitted, were not in form for immediate acceptance, and the Federal Emergenay Housing Corporation having been set up to act directly on the basis of grants, the Louisville sponsoring groups set out January 1, 1934, to prepare an application for a Federal slum clearanoe project, which was accepted by the Housing Division and progressed rapidly until the familiar adverse decision of the Federal District Court in December, 1934, abruptly ended not only this much-needed project, but all others throughout the country which involved Federal con14 demnation proceedings.

Meanwhile, in connection with their application, the

14 .Unitod States $v$. Certain Lands in the City of Louisville, 9F. Supp. 137 . 
sponsoring groups in Louisville had also sponsored a P.W.A. "Study of Housing Conditions in Certain Areas of the City of Louisville, Ky.", which was completed in February, 1934.

For these four areas, two on each side of and close to the central congested district of the city, very full information was made available in a well-prepared report, which also conteined convinoing photographs of typical bad housing conditions. Ground plan maps and aerial photographs showed how the land was overcrowded by buildings. The population of these areas taken together was about two-thirds Negro, though the proportion varies. The population has decreased in recent years as families sought better housing farther away.

Population of the 4 areas . . . . . 7,354

Proportion of total city population about . $3-1 / 3 \%$

These four areas were, therefore, samples of slum areas in Louisville, but could not be regarded as including more than a small fraction of such. This fact probably accounted for the apparently inconclusive results of the infant mortality and commicable disease studies. In spite of this handicap, the study showed the following differentials.

\section{Ratio of Cases to Population}

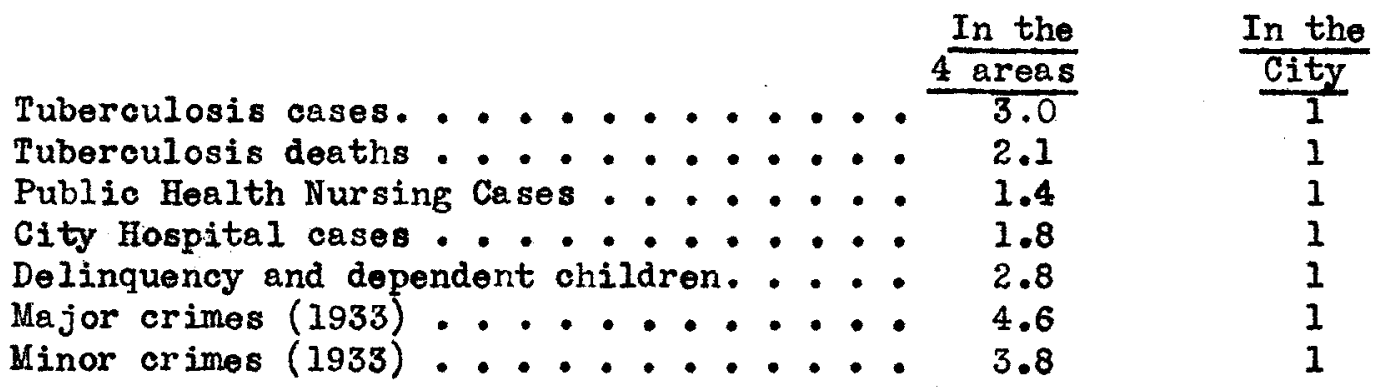


Structural Condition of Houses

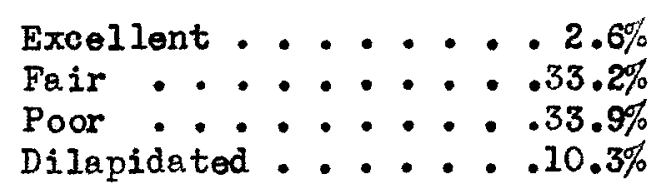

Proportion of adults in population ......... $73.6 \%$

Number of young children especially low.

Tenants paying from $\$ 3$ to $\$ 5$ per room per month .... $77.9 \%$

Dwelling units of 1,2 or 3 roons ........... $77.6 \%$

Having no water in the house ........... 28.0\%

Having no toilet in the house............ $64.6 \%$

In the case of water and of toilets, both indoors and out, they were somotimes private and sometimes shared with 1,2 or 3 families. Of outdoor toilets,. $49 \%$ were not connected with sewers.

Having netther bathtub nor shower. . . . . . $87.5 \%$

Dependent on oil lamps .............. $39.3 \%$

Thus we have a carefully documented statenent prepsred in 1934 in Louisville itself, by official and civic groups, showing the city's great need of slum olearance and low-rent housing.

The Louisville Advisory Committee on Housing wes appointed by the Administrator of Public Works, October 13, 1934, under the chairmanship of Dr. Kenneth P. Vinsel, uniting leading members of the three earlier groups active in the housing movement, to be the connecting link between Louisville and the Housing Division in Washington, D.C. This was done until state legislation was put into effect and a local Housing Authority appointed.

Due to the Federal District Court decision, voluntary purohase had to be substituted for condemnation. The Louisville 
Advisory Committee thus turned its efforts to finding sites which mot the new conditions. With their aid, representatives of the Housing Division chose the sites of the two present projects, La Salle Place and College Court, in Nay, 1935. Land purchases were concluded by September and the first contracts were let in December, 1935.

In 1934 the General Assembly of the State of Kentucky passed a law known as House Bill No. 585, allowing cities of the first and second olass to set up munioipal housing commissions with the power to establish, erect, maintain, and operate minicipal housing projects. With this as a background, a resolution relating to the creation of a Housing Commission wa drawn in December, 1936, and presented to the Board of Aldermen of the City of Louisville. On January 4, 1937, this resolution was passed, and three days later, Neville Miller, then Mayor of the City of Louisville, appointed the following comission: A. J. Stewart, Chairman; Harry W. Schacter, ViceChairman; Murray P. Nicol, Mrs. William Kirwan, Mayor Neville Miller, Ex-Officio. Mr. A. J. Stewart formed the connecting link between the new egency, the Advisory Committee, and the earlier civic groups interested in housing betterment.

The Louisville Municipal Housing Commission was allotted for the fiscal year of $1937-38, \$ 9,933$. This was the only cash amount set up for the operation of the local commission and its staff.

Although the Commission received no other cash contribution or appropriation, the services of the technical steff of the Planning 
and Zoning Commission were available to the Housing Commission. Today, there is also available to the Housing Commission all the valuable date and statistics that have been collected and summarized by the personnel of the Planning and Zoning Commission since its origin in 1927.

The Commission is a member of the American Federation of Housing Authorities, and a member of the Hational Association of Housing Officials.

In January, 1937, the Louisville Hunicipel Housing Comission made application to the Housing Division of P.W.A. for a $\$ 5,000,000$ grant for a slum olearance-low-cost housing project. Although no funds were available at that time, the application was given favorable consideration. In early December, 1937, Louisville began preparation of a new application for a similar projeot, and, on December 16, 1937, the Administrator of the United States Housing Authority earmarked for the City of Louisville $\$ 4,000,000$ to be spent in the construction of a slum clearance-low-cost housing project. On Februery 14, 1938, the application, begun the previous December, was finished and forwarded to the United States Housing Authority. The buildings were planned and are being erected at the time of this writing. On February 6, 1938, Louisville's two low-cost housing projects, begun under the Housing Division of P.W.A. and mare recently trensforred to the United States Housing Authority, were formally dedicated. Leases between the United States Housing Authority and the Local Commission were formally signed, and the 
Comission is now operating La Salle Place and College Court. La Salle Plece offers 210 completely equipped units to white families of the low inoome groups while College Court affords 125 similar units to members of the Negro race. It is interesting to know that the Louisville Municipal Housing Commission was among the first to sign such leases under the new Authority. College Court will be more specifically discussed in the next chapter.

Mr. J. Austin Latimer, assistant to Nathan Straus, Administrator of the United States Housing Authority, was principal speaker at both dedicatory oeremonies. Prior to the dedication, 100al newspapers were extremely cooperative in publicizing the work of the Municipel Housing Commission and the Planning and Zoning Conmission, which led to the construction of these two projects.

On February 1, 1938, the Commission entertained Captain Richard L. Reiss, of London, England, at a dinner speaking. A large number of Louisville's leading citizens interested in the city's housing problem attended the dinner.

A forward step in the State of Kentucky was taken in March, 1938, when representatives of seven cities interested in housing gathered in Louisville at a meeting sponsored by the Local Commission, and organized the Kentucky Housing Assooiation.

Later in March, the Housing Commission, along with the City Planning and Zoning Commission, gave its approval as co-sponsors to the current Real Property and Low Income Housing Area Surveys. The Work Projeots Administration agreed to supply the necessary 
workers to serve in the oapacity of enumerators and tabulators incidental to the field survey and final compilation of statistics. Through the survey the two Commissions expeoted to have a complete and up-to-date picture not only of all structures, but a thorough knowledge of the families that ocoupy them as woll.

On Friday, May 13, 1938, several thousand people gathered on a site soon to become our first slum clearanoe low-rent housing project, to witness the beginning of demolition of all structures in this area.

Mr. Warren J. Vinton, Chief Economist and Planning Offioer from the United States Housing Authority, made the principal address. Other speakers included Mayor Scholtz, Chairman, and Vice-Chairman of the looal Commission, all of whom pointed out the progress Louisville has made in attempting to find a solution for its urgent housing problems.

As the purchase of properties in this nine block area began, the Commission found it necessary to locate on this site a district office, to aid the tenants in moving from the area in finding suitable quarters during the construction period. Every effort was made to find coraparable or better housing at such rents as these families could afford. Social agenoles were asked to cooperate, lists of available vacancies prepared and advice was offered by the district personnel.

Louisville received its third earmarking of $\$ 5,000,000$ on September 30, 1938, when U. S. Housing Authority officials announced that this anount had been set aside for a third project 


\section{in Louisville.}

On October 12, 1938, the City of Louisville Municipal Housing Comission advertised for bids for the construction of a project known as KY. 1-1 to house 786 white frmilies, and on November 16 bids were formally opened, read and tabulated in the presenoe of several hundred local and out-of-town cortractors who had submitted bids for the various branohes of construction, incidental to the proposed project.

Decomber 29, 1938, is a significent date in the history of the local Commission, as it marks the actual boginning of Louisville's first slum cloarance low-rent housing project. On that day several hundred people gathered on the site of the proposed Negro project as Mayor Scholtz turned over the first. soil in that area.

The interest of civio organizations, labor groups, and social agencies is increasing steadily. The Comnission, in a final statement, maintains that although the building of some 890 now units and the demolition of approximately 990 definitely substandard will not entirely solve Louisville's housing problem, it will be a most significant start in meeting the local situetion. 
III. COLLEGE COURT--A HISTORY AND INTERPRETATION 
COLLEGE COURT-A HISTORY AND INTERPRETATION

According to the sociology departinent of the Municipal College for Negroes, Negross live in practically every part of the city. In many instances each small Negro area is a cross section of the various social classes. In the older sections of the city, alleys divide each block into two or four parts. Quite frequently these alleys are unpared and the houses merely shacks. This means a class difference in nearly every block. Since, according to the 1932 City Directory, 90\% of the alley dwellers are Negroes, Negroes nay be found living in most of the better residential areas.

The concentrated Negro area in Louisvilile is a strip seren blocks wide, beginning just west of the central business district and extending for twenty-five blooks (6th to 3 lst Streets). The east-west streets begin with Broadway on the south and include Magazine, Chestnut, Madison, Walnut, Cedar, Liberty, and Jefferson. In this area Negroes constitute $65 \%$ of the population $(19,630$ Negroes to 10,678 whites, according to 1930 Census. The morement of Negroes has been chiefly westward, and toward the extreme west end of the area the Negro population thins out appreciably. West of 31 st Street there are very few Negroes except those who live in alleys.

The western end of this area is the most desireble residential distriet for Negroes in the city. A decade ago to live on Chestnut 
Street, west of 2lst Street, was indicative of high social position. Walnut Stroet is only slightly below Chestnut in prestige. Magazine and Madison Streets are next in importance. The cross streets do not rank with the streots previously mentioned in desirability for residential purposes.

Negro business and professional life centers around 6 th and Walnut Streets. This area (6th to 14th--Broadway to Jefferson) include's also the concentrated vice district. Between this congested district (6th - 14th) and the residential area previously mentioned (2Ist - west) Iles an area (14th - 2lst) not quite so desirable for residential purposes yet free from most of the undesirable foatures of the slum area. Many old and respected Negro families live in this area, but the area itself does not now have the prestige of the district farther west.

All of these Negro districts west of 6th Street and between Broadway and Jefferson are referred to as "Downtown". The "East End", or "Uptow", begins with Ist Street and extends east nine blocks to Beargrass Creek. Negroes constitute about $40 \%$ of the population. Broedway divides the "East End" into two sections. The northern section (Broadway to Market) is only $28 \% \mathrm{Negro}$. It has boen perhaps the worst slum area in the city. Within this area is the site for the four million doller slum clearance project for whites. (A corresponding project for Negroes has been provided for in the

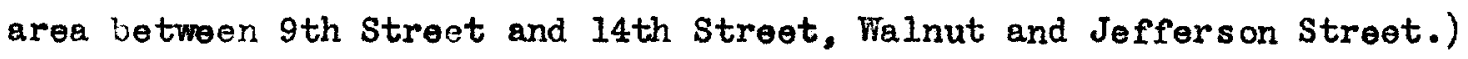
Most of the Negroes live in the alleys in this "East End" section. 
There has been no movement into this area of Nogros of the higher income brackets. In fact, it is maintained that it is probably an area of decreasing Negro population. The white slum clearance project has necessitated the removal of a large number of Negro families which makes the area no longer important in the Negro comminity.

The southern section of the "east End" is familiarly known as "Smoketown". This is an old and respectable residential section, although in recent years its respectability has deolined somewhat because of the migration of some of the old settlers to other perts of the city. This area is almost a self-contained community and its inhabitants are strongly group conscious. Within this area are located, among other things, one of the two junior high schools for Negroes, a branch library, a recreation center, a day nursery, and a neighborhood theater. No other Negro area outside the central area has any of these things.

There is a Negro Community of 2,500 people living in that seotion of the city lying south of Broadway and between 15th and 18th Streets. This comnity is separated from the larger Negro area by an intervening area of underprivileged whites. This area is commonly known as "California". The name perhaps arose during the early period of the eity's history when the area was near the south-west corporation limit. At the present time the most desirable residential streets are Dumesnil and Orms by which are near the southern boundary of the district. 


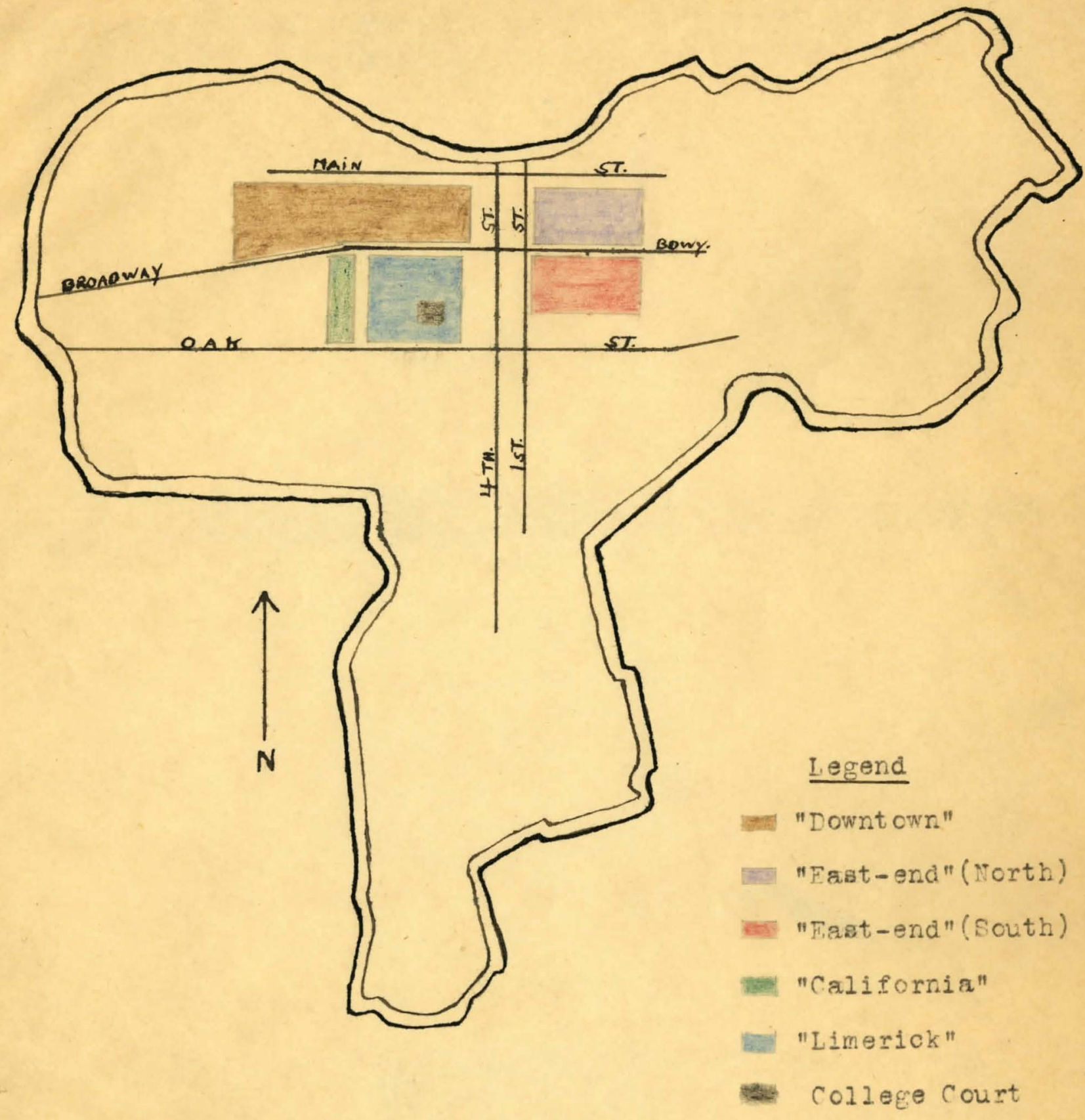


Between 7th and 15th Street, and south of Broadway are several adjacent Negro areas. Toward the southorn city boundary are Bingham and Cabbage Patch. Between Broedwry and Oak Street is Limerick, an area formerly dominated by the Irish but now taken over by Negroes. This is the area in which College Court is located. Railroads and factories make the greater pert of this area undesirable for residential purposes. However, the presence of the Louisvillo Municipal College for Negroes and of College Court itgelf is bringing about a change in the residential quality of the eastern seotion of this area.

Although it was fully realized that conditions were bad among all races, the Louisville Planning and Zoning Comission docided, in 1931, that it would be expedient to study the Negro situation first. The necessity for the determination of actual conditions led to an investigation of all Negro sections. The survey covered 165 blocks throughout the city and disclosed very interesting and significant facts. For example, it was found that $24 \%$ of all the buildings investigated were in bad repair and thet only $21 \%$ were in good repair. Only $21 \%$ of the houses had inside toilets, whereas $35 \%$ had toilets in the yard and $44 \%$ had open vaults. From a health standpoint these figures are of great importance.

Investigation of the size of families disclosed the fact that Negro families are materially smaller than whites. Sixty-nine per cent of the occupants of single family dwellings were adults. Twentytwo per cent were children of sohool age and nine per cent were children of less than sohool age. Of the occupants of multiple family drellings, 
$76 \%$ were adults, $16 \%$ children of sohool age and $8 \%$ were children below school age. The average size family coupying single family houses was 3.9 persons as compared with 4.4 persons per family for corresponding wite groups. In the multiple family groups, there were only 2.1 persons per family compared with 3.5 persons in white families occupying multiple dwellings. For various reasons the natural increase in population among Negroes is much less than among white persons, in fact the annual Negro death rate in Louisville (16.9 in the year 1939) is greater than the birth rate $(13.5) .^{15}$

In the 165 blocks studied, $95 \%$ of the dwellings rented for less than $\$ 25$ per month, a great majority of the houses renting for about $\$ 4$ per room per month. Rentals paid in multiple family houses were approximtely the same when reduced to a rent-per-room basis. The economic situation among the Negroes is disclosed by the fact that $90 \%$ of all the families have incomes less than $\$ 75$ a month. Even under normal conditions more then one-half of the families are in this low income group.

From the results of the survey it is apperent thet in order to reach the bulk of the Negro population, any new housing whioh is provided must rent for not more than $\$ 5$ per room per month. The well to-do Negro who can afford higher rentel does not constitute a serious problem as there are many places available that will provide him with comfortable living quarters.

The total Negro population in Louisville, according to the

15. Health Calendar, Health Council of Louisville, April, 1940. 
1930 census, is approximetely 47,350 . In the fifteen areas studied by the City Planning and Zoning Commission the Negro population was 40,470

In the area with which we are conoerned the Negro population previous to the establishment of College Court was $2,765,12.58 \%$ Negro. This area lies from 5th Street to 10th Street and from Broedway to Oak Street. It included $2.67 \%$ of the total Negro population in all areas.

An analysis of Teble I reveals that the "IImeriok" area (5th to 10th - Broadway to Oak) has not a relatively high percontage of Negro population. The per cent of struotures unfit for use is not exceptionally high in this area. The congestion rate for the areas considered does not seem to be influenced by the per cent of Negro population. The congestion rate for the "Limerick" area is not a larmingly high in comparison with areas $4,6,9$ and 10 . It will be noted that the Negro tuberculosis death rate is higher for the "Limerick" area than for any other area. It is to be remembered that factories and railroads are prevalent in the area. It is a matter of opinion as to whether this fact influences the tuberculosis death rate.

Table II indicates that the presence of College Court had some statistical effect on the area. The total number of families in the immediate four-block area considered (a more limited district than that dealt with in Table I) is considerably increased. This might well reveal that College Court drow its tenants from neighborhoods other than its own. The per cent of families having residenoe 
TABLE I

COMPARISON OF NEGRO HOUSING (1934) AND TUBERCULOSIS DEATH RATE (1931-36)

\begin{tabular}{|c|c|c|c|c|c|c|}
\hline & Area & $\begin{array}{c}\text { Per cent } \\
\text { Nogro } \\
-\end{array}$ & $\begin{array}{c}\text { Per cent } \\
\text { Structures } \\
\text { Unfit for } \\
\text { Use } \\
\end{array}$ & $\begin{array}{c}\text { Congestion } \\
193416\end{array}$ & $\begin{array}{l}\text { Negro T.B. } \\
\text { Death } \\
\text { Rate } 7\end{array}$ & $\begin{array}{l}\text { Per cent of } \\
\text { Hegro Popu- } \\
\text { lation in all } \\
\text { areas }\end{array}$ \\
\hline 1. & $\begin{array}{l}\text { 6th-14th } \\
\text { Bdvy-Jeff }\end{array}$ & 93.21 & 29.16 & 5.78 & 332 & 15.66 \\
\hline 2. & $\begin{array}{l}\text { 14th-21st } \\
\text { Bdwy-Mlarket }\end{array}$ & 76.88 & 13.10 & 2.77 & 180 & 14.80 \\
\hline 3. & $\begin{array}{l}\text { 2lst-West } \\
\text { Bdwy-Market }\end{array}$ & 34.78 & 2.46 & 1.51 & 120 & 11.53 \\
\hline 4. & $\begin{array}{l}\text { 10th-15th } \\
\text { Bdwy-Orms by }\end{array}$ & 63.97 & 18.24 & 11.38 & 175 & 8.48 \\
\hline 5. & "California" & 31.21 & 6.03 & 3.07 & 110 & 8.08 \\
\hline 6. & "Cabbage Patch" & 40.01 & 13.29 & 11.16 & 130 & 3.79 \\
\hline 7. & South Louisville & 11.00 & 1.68 & 5.09 & 25 & 1.96 \\
\hline 8. & Grand Avenue & 13.51 & .40 & 1.07 & 0 & 2.40 \\
\hline 9. & Little Africa & 77.36 & 22.27 & 5.95 & 98 & 5.54 \\
\hline 10 & East End & 25.11 & 14.78 & 14.62 & 324 & 7.94 \\
\hline 11. & "Smoketown" & 54.88 & 7.55 & 3.80 & 132 & 10.51 \\
\hline 12. & Fort Hill & 35.91 & 5.78 & 6.55 & 165 & 4.72 \\
\hline 13. & "Limerick" & 12.58 & 3.95 & 3.50 & 352 & 2.67 \\
\hline 14. & Highland Park & 8.77 & 4.24 & 9.60 & 186 & 1.06 \\
\hline 15. & Portland & 7.23 & 6.17 & 2.21 & 229 & .86 \\
\hline
\end{tabular}

Source: Dr. Charles Parrish, Professor of Sociology, Hunicipal College for Negrces.

16. Per cent of all (Negro and white) cecupied dwelling units with two or more persons per room.

17. Arerage yearly rate per 100,000 population includes city deaths at Waverly Hills. 


\begin{tabular}{lcc}
\hline & $\begin{array}{c}\text { Without } \\
\text { College Court }\end{array}$ & $\begin{array}{c}\text { With } \\
\text { College Court }\end{array}$ \\
\hline $\begin{array}{l}\text { Number of inhabitants } \\
\text { Number of family units }\end{array}$ & 214 & 491 \\
Per cent ownership & 61 & 137 \\
Per cent multiple dwellings & 8.2 & 3.6 \\
$\begin{array}{l}\text { Per cent tenants paying rent } \\
\text { over } \$ 10 \text { per month }\end{array}$ & 31.3 & 43.8 \\
Per cent tenants paying rent \\
under $\$ 5$ per month
\end{tabular}

Source: Dr. Charles Parrish, Professor of Sociology, Municipal College for Negroes.

under one year is also increased by College Court's presence. This increase may diminish as College Court grows older.

In turning to the question of jurenile delinquency in relation to a neighborhood's need for housing, it oan be said thet in the United States the increase in delinquency during the past few years among Negroes in large cities probably has been lergely due to the segregation 
of Negroes into areas of deterioration. This segregation has hindered the Negro in his readjustment from a rural life to an urban life. Studies of jurenile delinquency in the representative communties have frequently noted that the Negro race contributes delinquents in numbers fer out of proportion to its ratio in the whole population. The existence of high concentration of delinquency among Negroes in areas of worst housing indicates that the high delinquency rates among Negroes are due, at least in part, to the congestion and unfarorable aspeots of housing common in their homes.

For the years 1925-1930 the juvenile delinquency rate for Negroes in Louisville was 547 per 100,000 population. For the area with which we are concerned, Broadway - Oak; 5th - loth, the rate was 656. In 1935 there were 33 juvenile delinquents, 27 male and 6 female, coming from an area bounded by 7 th street on the east, Broadway on the north, 15th Street on the west, and oak Street on the south. This same area contributed 25 delinquents in 1936, 22 male and 3 female.

There were no juvenile delinquents who moved into College Court upon its establishment. The principal of the elementery school opposite the project has stated in no uncertain terms that the children from College Court, with but one or two exceptions, are the best disciplined children in the school. From an observation made by the staff of teachers of the school, the children's general appearance and morning health inspection have a higher rating than those of surrounding 
communities. In only a few short months after the completion of College Court there appeared a tendency on the part of the associates of College Court children to imitate the better qualities of these children.

However, it is the expressed desire of those conoerned with housing that more "so-called" juvenile delinquents actually move into the projects. Only then can accurate measurement be taken of the effects of better housing on children with behavior problems.

In our discussion of a neighborhood's noed for housing we might well say that the area in which College Court is located was no more in need of better housing than eny other area populated by Negroes. However, College Court is a low-rent housing project and not a slum clearance project. Land for better housing construction had to be obtained where it was available.

In the early part of 1935, following a moeting with the Director of the Housing Division of the National Recovery Act in Washington, the Citizen's Comittee on Housing filed a preliminary application for approval of a loan for a low-cost Negro Housing Projeot in Louisville. As was pointed out in Chapter II, due to the Louisville Court decidion, voluntary purchase had to be substituted for condemnation. The Louisville advisory cormittee was campelled to turn its efforts to finding sites which met the now conditions. With the aid of the members of this committoe, representatives of the Housing Division in Washington chose the site of College Court in May, 1935. Land purcheses were concluded by 
September and the first cantracts were let in December, 1935.

College Court had been endorsed by the Board of Directors of the Louisville Board of Trade, and by the Board of Directors of the Real Estate Board. The Housing Committee had selected the site of the old Eclipse Ball Park, located on Kentucky Street between 7th and 8th Streets, on which it proposed to erect a group of model dwellings housing 140 Negro families. College Court was estimated to cost $\$ 375,000$ and to provide seven months' work for one hundred and fifty laborers. The project was in accordance with the Federal program for the coming fall and winter seeson.

Under the National Recovery Act, the Government loaned money to limited-dividend housing oorporations to the amount of $85 \%$ of the cost of the project, the remaining $15 \%$ being raised locally. Labor employed on the work was paid wages ranging from $\$ 1.10$ per hour for skilled to $45 \not$ per hour for unskilled labor, based on a 30-hour week. In the case of College Court, the Federal Government paid in back taxes $\$ 2,020.45$. In current taxes, $\$ 972.11$ was paid. $\$ 23,500$ was paid in mortgages and other liens. No expense was incurred either by the city or the Federal Government for street paving, sewer or water mains. These were already adequate.

Registration for potential tenants of College Court began on December 23, 1935. Registrations for application for residency had been accepted months in advance. These registrations acoumulated. However, when notices were sent to those registered stating the time for formal application, my did not respond. Some had moved, others 
had lost interest, others were no longer in a family situation. The tenant selection procedure is designed to provide a method of determining from a large number of applicants the families who best comply with the particular standards of eligibility and conditions of ocoupancy established for each Housing Division project.

Tenant selection procedure falls into three major subdivisions:

1. Taking of applications.

2. Investigetion of eligible applioants.

3. Certification of eligible applicants to the Renting Department subsequent to investigation.

These three principal subdivisions are broken down into the individual steps through which a prospective tenant's application must pass before he is eligible to sign a lease.

Formal application began for College Court on September 25, 1937. On December 27, 1937, the first tenant moved in. The maximum inome allowed for those with two minor dependents requesting fiveroom apartments was $\$ 1,800$ per yoax. For those with three minor dependents requesting five-room apartments, 2,218 was the maximum income.

For those noeding four-room apartments, $\$ 1,600$ per year was allowed as the maximum income. Three-rocm apartments necessitated not more than $\$ 1,300$ per year. These maximum income figures were fixed as not more than five times the rent figure.

Where lower incomes were concerned there was more flexibility. A normal family budget was arranged. The actual budget of a family under consideration was estimated. If it was found that the budget of this given family was below the normal and yet 
the family was still able to pay the rent in its present circumstances, that family might be admitted to residency.

Visits to fanilies applying for apertments are recuired in the tenant selection procedure. Observation is made in regard to the family's prosent housing situation. Housokeeping techniques are observed. Heatness, cleanliness and sanitation all serve to make a general impression on the visitor. If the type dwelling in which the family lives is found already quite setisfactory, the case is excluded from among those applicants to be considered for the project. This is the second basis upon which an applicant may be rejected, the first being the question of income.

Family references and prompt payment of bills are investigated. Former neighbor relationships are checked. It is found during the course of this type study that people are usually prone to speak in favor of the applicant concerned in order to avoid incriminating evidence. It is doubtful whothor this mothod of reference investigation is to be justified because of its apparent "back-door" technique. Further, it is scarcely probable that much authenic information can be obtained due to the indirectness of the method. Such questions as "Do the applicants quarrel?" and "Do the children play well together?" are very relevant to the subject, but are often not answered very satisfactorily when answered by mere aoquaintances of the applicant. "Are they poor financial risks?" is a question which can be answered only by persons who have had business relations with the applioant.

All applicants are scored up to 100 points. Those receiving 
below 60 points are rejected.

When certified, the tenonts, now newly selected, are sent notice to ocme and sign the necessary papers.

When the new tenants move into the new project they are visited by a "staff member" and "made to feol at home." The visitor asks each tenent for suggestions and criticisms which would influence lifo within the project. Many tenants make some very sane and valuable suggestions.

A list of waiting applicants must be checked from time to time and kept up to date. Each housing project has a social worker on call whose duty it is to check this waiting list at intervals.

One hundred and twenty-five modern dwelling units ore provided in College Court, a $\$ 776,000$ project. The project includes two, three, four and five-room individuel homes. In each dwelling is a table top gas stove, mechanical refrigeration, adequate kitchen cabinets, composition flooring, steel fremes and casenent windows, individual beck yards and central heating system. Playgrounds and other reoreational features are provided for children and adults, and more than $80 \%$ of the project is laid out in landscaped courts and gardens.

One rule of the project is that repeirs to things broken by tenants will be charged to them, but breakage not the fault of the tenant will be paid for by the person responsible.

Approximately 3,000 persons were conduoted through College Court on November 14, 1937. Two dwellings were completely furnished to show how a family can decorate a home simply and at an oconomical 
cost. Because of the enthusiasm and the keen interest in College Court displayed by Louisville citizens, another inspection tour was held on Norember 21st, and yet another on November 28th. Visitors heard in detail the workings of the plan.

On February 6, 1938, the impressive public dedication exercises took place in the center court of College Court. The essembled crowd coverod a.ll available walks. Mr. J. A. Thomas, Chairman of the Louisville Urben League and the dedication committee, served as master of ceremonies during the program of music and addresses.

The Reverend W. P. Offutt, pastor of the Calvary Baptist Church, opened the program with an invocation. This was followed by masical selections from the Booker T. Washington Comnunity Center band.

Mr. A. J. Stewart, then chairman of the Municipal Housing Comnission, delivered an address on the purposes and progress of Louisville's housing progrem. Chairman Thomas followed with a talk on the significance of College Court for the Negro population of the city.

Mr. J.A. Latimer, Washington representative of the Notional Housing Authority, appropriately turned over to Mayor Scholtz tho keys to Colloge Court, and with the Mayor's acceptance at 4:25 P.M. the Municipel Housing Commission assumed control of the project. Opening the second part of the program, the Louisville Municipal College chorus sang several selections. The Negro Boy Scouts, who acted as ushers during the services, were in charge of 
the flag raising. The audience sang "Amerioa" and "The Star-Spangled Banner" during the raising, and with the benediction by the Reverend C. I. Russell, pastor of the Chestnut Street Methodist Episcopal Church, the dedication cane to a close.

Immediately upon taking up residency, the residency beginning several weoks previous to the dedication, the new tenants of College Court, according to their own statements and information received from workers in close contact with them, began to acquire a feeling of sociability. In the beginning they were rather lonesome, and suggestions vere made by the social worker as to the neighboring tenants with whan they could most conveniently and enjoyably make friends.

Answers to questionnaires distributed among the tenants revealed that a few of the residents limited their closest friends to College Court. That is, out of seventy-five answers to the question, "Would you sey thet your olosest friends were inside College Court or outside?", thirty-two designated outside, thirty both inside and outside, and only thirteen stated that their friends were primarily inside. This implies that College Court residents were not and are not solely dependent upon neighboring tenants for social relationships and companionships. It might be said that the now tenants' main problem was becoming adjusted to a totally new housing arrangement together with a very limited number of regulations.

In any tenant adjustment situation there is no doubt that the resident manager plays a leading and important role. The 
strangeness and the regulatory features of a housing project are more familiar to the manager than to the tenants who are about to assume residency. It is natural, then, that the resident manager should be most helpful in aiding the tenants in their understanding of a new environment. Day by day many problems involving both the physical building and its inhabitants arise. These problems aro unpredictable. They emerge unexpectedly, and they are insistent in their demand for a quick intelligent answer. To supply such answers is the job of the housing manager. The effectiveness of his answers will depend upon his ingenuity, his resouroefulness, and his understanding of people.

As $f: r$ as tenant adjustment in College Court is concerned, interviews with tenants never revealed any difficulty. It must be understood that the residents of College Court were and are rather well educated and were not and are not from the very low income group. This assures a more natural and easy adjustment. The more socially adjusted a prospective tenant may be before residenoy the more easily he becomes adjusted after residenoy.

We have stated that the residents of College Court did not come from the neighborhood in which College Court is located. Of ninety-one residents answering the question concerning previous address, seventy-four were found to have lived in other ereas previous to College Court residency, as against only seventeen having lived in the College Court or "Limerick" area previous to . residency. 
Seventy-nine recorded occupations of College Court residents revealed twenty-six porters, sixteen domestic servants, nine waiters, six laborers, five pressers, three insurence agents, two ministers, two moulders, one postman, one linotype operator, one phermacist, one bartender, one U.S. deputy collector of internal revenue, one messenger, one registered nurse, one perk policemen, one visiting teacher and one landscape attendant. However, College Court residents are, for the most part, occupied as porters, domestics and waiters. Thus a high proportion of late a fternoon and evening work is required of these people. Lete working hours afford them a minimum of time for cultivating neighborliness and friendships within College Court.

Eighty-three recorded answers to the question, "Did you belong to any clubs, fraternal organizations, unions, etc., before College Court residency?" revealed that forty-two residents or fifty per cent had belonged. Numerous social clubs were listed among the organizations to which they had belonged. Other organizations included various church groups, several unions, the Masons, the Central Democratic Club, a ministerial association, a sewing circle, several fraternities, the Eastern star and several choruses. These organizations and clubs received the tenants' attentions before College Court residency. Needless to say, the affiliations were not, except in rare cases, discontinued because of residency in a housing project. Of the forty-two residenta stating thet they belonged to various organizations before College 
Court residency, only twelve no longer belong to any organizations outside College Court at the present time. These twelve may have discontinued their membership in the above mentianed organizations and olubs due to chenge in address or other reasons. The remaining thirty retained their previous affiliations, and four of these thirty joined an additional organization outside College Court. of those residents stating that they did not belong to any organization or club previous to College Court residency, only three joined such an organization outside of College Court after moving into the project. This is not a significant change. Those belonging to organizations within College Court will be considered in another chapter.

Eighty-five out of ninety-six residents interviewed attend church regularly outside the project. These church affiliations present opportunities for social relationships outside College Court. The church plays a prominent part in the lives of most of the College Court residents.

Personal interviews with residents of College Court revealed several interesting statements in regard to environmental adjustment. One tenant stated that she had no time for clubs until she moved into the project. For one reason, her children were not as adequately provided for as they are now in College Court. Thus she has more leisure time of her own at present. The same resident stated that at first the children moving into the project were timid and easily antagonized in their play activities, but now they play together 
quite easily and readily. "There are so many different natures in people that you don't realize it until you live together with them," philosophized this interviewee.

Another resident stated that, "One is able to save by living in the project. The rent is peid more easily and when the rent is paid a good many things are paid. My husband and I wouldn't live any place else now."

"It was winter when College Court first opened for residency," explained another tenant, "therefore the tenants remained indoors for the most pert. However, as the weather improved and became warmer, the residents began to see one another more often and friendships developed."

No quarrels or open displays of misunderstanding have ever been evident at College Court. One such example of tenants' failure to adjust properly is seen in New York's Lavanburg Homes and noted by Mr. Abraham Goldfeld, the resident manager.

19. The Diary of a Housing Manager, National Assooiation of Housing
Officials, 1938 , pp. 39-40.
"Mr. Dubin complained about Mrs. Marous, who had created a camotion in the hall of her section. It all began from quarrels among the children. Others joined the quarrel and it seems that Mrs. Marous cursed Mrs. Dubin. The latter, superstitious by nature, feared some evil might befall her. Mr. Dubin was careful to report that $\mathrm{Mrs}$. larcus in her fury had even included me in her denunciations. Later, when Mrs. Marcus called at the office in reference to another matter, I asked her about the incident. She stated that Mrs. Dubin had made insulting remarks to her child about the manner in which she was dressed, and Mrs. Marous felt justified in retaliating as she had. She keenly foels the slurs cast upon the appearance of her children's clothes but is helpless because she has not known economic security for a long time. In addition, she had been very ill for the past week and had found it difficult even to feed her children properly. Her husband had assisted by preparing food in the morning before going out to look for work. She was very bitter in her attitude toward her neighbors, who, she declared, are unfriendly." 
Tenant problems and adjustment can become a very serious matter especially in the life of the resident manager. Only one resident interviewed in College Court seemed to feel that some of the tenants were unfriendly toward her. This one tenant's attitude can probably be explained by the fact that she further states that the poople in Louisville as a whole are unfiendly and difficult to get along with.

It must be remembered that the fundamental purpose of a housing programme is not to provide emergency employment, nor to satisfy the ego of professional "housers." The purpose is to provide housing for those who need it.

Thus the success of a housing programme can only be judged after the carpenters and plumbers have locked their tool boxes and gone their way. Their work is completed when the tenants have moved into the apartments. It is only then that we may begin to judge fairly the value of the labor that has gone to make the housing projects. The place of College Court in the community surrounding it is not phenamenal. A Negro school composed of portablo buildings is immediately across the street from the projeot and can expand its facilities if necessary. In the near future the School Board plans to put a modern builiing on this site with commuity facilities. We have already mentioned the part played by College Court children in sotting an example for other childron in attendance at this school. The Municipal College for Negroes affords College Court residents splendid opportunity for higher education. Many adult tenants attend night classes, a few of college age attend full-timo day classes, most of the few high school students in the project 
have aspirations to attend the Municipal College. It might be said that the Municipal College is fortunate in having the Negro housing project placed where it is, direotly across the street. The University of Louisville originally decided to purchase the property of Simnons Oniversity, and make it a center for college oducation for Negroes, particularly because of the desire of those in charge of that institution to sell their property due to the debt which was on it. The location was one which for many years had bees associated with college education for Negroes in Louisville. It was well located with respect to its probable clientele. The purchase was made, therefore, in spite of the fact that its immediate environs at the time were not all that could be desired. Even then, however, it was hoped that in the not too distant future this latter situation could be materially improved. With the construction of College Court the Hunicipal College for Negroes finds its physical environment improved and its student body numerically increased.

Before the advent of College Court there was no park or playground for Negroes within two miles of the site where the project is now located. Housing authorities recognize recreation as an important phase of individual and community life and agree that provision must be made for recreation in every housing development. The play space and playground with in College Court is not limited to the residents of the project alone. Thus, play spece is available to neighborhood children outsid the project, and is used accordingly. The recreation room in the project is much in demand by 
outside individuals and groups. Groups wishing to secure the College Court recreation room are requested to make reservations in adrance. Each reservation and request must be approved by the manager so that no conflicts will ocour. Outside groups requesting the use of the recreation room have included several church organizations, a beauticians" club, a West End relief club, several glee clubs and several purely social clubs.

Interest has been shown by the tenants throughout College Court and by residents in the community in bettering their living conditions in every respeot. This attitude has tended to attract into the project mombers of the surrounding community who have expressed a desire to live in such a project, and who avail themselves of every opportunity to partake of the community activities which the project has to offer. College Court's social affairs, moving picture shors, health demonstrations and other programs are attended in a large measure by the neighboring community.

Actual clubs and leisure time activities touching the lives 2 of the people outside College Court will be considered in the next chapter. At present it is enough to say that a neighborhood's need for housing has been partially, but only partially, answered in College Court; that the tenants were selected carefully and have adjusted well to a now environment, and that College Court has a part to play in the community in which it is located. 
IV. GROUP LIFE AND LEISURE TIME FITHIN THE PROJECT 
GROUP LIFE AND LEISURE TIME WITHIN THE PROJECT

Good housing is not an end in itself, but a means to attaining the good and abundant life which is, consciously or unconsciously, the objective of us all. Its importance lies in its aid to physical, mental and moral health, which are themselves the elements out of which a wholesome family life is built. Family life means more than its biological functions. Recreation and eduoation are normal human needs. Children and adults need indoor and outdoor play space. They also need social contrets. Family life at its best expands into neighborhood life.

In the future the success of the public housing movement will be measured chiefly on the basis of its contribution toward making human life happier and richer. Fruitful and satisfying use of leisure time is one of the ways to be happy. Public housing bodies, therefore, cannot fail to take this opportunity to include in their plans facilities for leisure time activities.

To a man standing in line before a factory gate, begging for work at an employment agenoy, or tramping city streets in the drab and desperate search for a job of any sort, discussion of the use of leisure is touched with a tragic irony. There are in the United States millions of men and women for whom the word leisure has this ironic implication.

Leisure as used here, however, has nothing to do with the 
enforced idleness of the unemployed or the activities of those acoustomed to wealth.

Today for the child of the avarage city worker the street alone is the great outlet for recreation. An occasional settlement house or playground cannot meet the competition of the motion picture house, the pool room, the swarming life of the streets. There is little in the dingy home surroundings of the tenement child to keep him at home. To play, the chief concern of the growing child, he must be with his fellows, and the setting for his play is almost of necessity on the street, with its physical and moral hazards.

Cities exist for other and finer purposes then the wore sheltering of workers around factories and offices. Workers are human beings. We must provide for the human noeds of city dwellers, over and above stark considerations of bread and butter. To make our cities homes rather than barracks we must hereafter include in our rebuilding a wide range of facilities for true communal living. The outstanding pioneer in public housing, of course, was the city of Vienne under its socialist government. However, the world has been treated to the spectecle of the virtual destruction of the Vienna projects by the former Austrian Government. Early in February, 1934, the Dollfus forces, in attempting a complete supression of the Socialist Perty, centered their armed attack upon, the municipal houses. It was in these houses that group life developed into social action. Socialists the world over had held up the municipel housing projects of Vienna as brick-and-mortar models of what the cooperative commonwealth might look like. 
They had pridefully shown spacious, sun-flooded apartments of genuine architectural beauty, comparable to any American apartments in exclusive residential districts, wherein workers, skilled and unskilled, might be housed at amazingly low rents. More than 50,000 families had been comfortably housed amid the beautiful surroundings of the 54 municipal housing developments in the city. They had the luxury of light and air, unknown to our slum dwellers; their children could play upon enclosed grounds away from traffic, and go to the best of kindergartens and schools. The houses included wading pools, play spaces, nurseries and gymasiums. In cooperation with various city depertments, the municipality provided libraries and medical and dental clinics for the people living in the new apartments.

There are factors that have bearing on the conduct and success of activities in housing projects. Homogeneity or the lack of it among the people who constitute the community is important. Another factor of import is the previous background of the residents. People who have been participents in settlement programs readily adopt similar activities when they are incorporated in the housing scheme. On the other hand, a suburban and higher income group demands a more costly, sophisticated and varied program of activities. College Court may find itself in this latter situation.

At any rate "all people have sme leisure--that amount of time remaining after the necessary 'bread and water' things of life have been attended to--that time in which the individual may do the things he most enjoys. Whether this enjoyment takes the form of an organized game or a parlor trick determines the type of 
the individual participant or his adaptability to supervised leisure 20

time direction."

In College Court the response to the rork and effort of the management and recreation leaders, both paid and volunteer, has been somewhat gratifying. However, there have been times when those efforts seomed in vain. This was due first to the limited number of tenants and the small number who availed themselves of the opportunity to engage in volunteer leadership. Again, orer fifty per cent of the tenents are domestics and have little time to devote to social activities. Therefore such activities have been carried on with a "faithful few." In many oses some of the same people take part in several types of activities.

According to the manager of college Court, one of the most difficult tasks of a housing manager in organizing various programs is to find material in the form of capable, interested and willing people. Such individuals must be developed into volunteor leadership. This must come about through the engendering of good will and educating the tenants to the idea of community life and activity.

\section{The College Court Glee Club}

The manager at College Court first discovered men and women who had the ability to sing and who had training not only in singing but in teaching as well. A meating was organized with these individuals, and the manager discussed with them at length the purpose

20 Wilson, Elizabeth A., "Recreation in Louisville--An Historical Sketch," Unpublished M.A. dissertation, Dept. of Sociology, Unitersity of Louisville, 1938, p. 3. 
and philosophy of the United States Housing Authority. This philosophy was readily grasped and an arganization was formod known as the College Court Glee Club. This was on April 4, 1938. It was the first club, organization or leisure time activity arganized in College Court. The purpose of the Glee Club was to stimulate musical interest among the tenants and to find musical talent and help develop it. The group elected a president, secretary, a treasurer and business manager, and chose a pianist. Seventeen members belonged to the club with an average attendance of eleven. The Glee Club met four times each month in the sooial room with fifteen minutes deroted to business and one hour to rehearsal.

The Glee Club helped to "put over" progrems with other clubs, both financially and with musical selections. The club's first public rendition was "Silhouette in Song," given in order to help one of the tenants, the pianist, with a final drive for one of the local churches. A trip to Elizabothtown, Kentucky, to aid in another project for a church in that community is included in the list of activities sponsored by the Glee Club. Money was raised for the purchase of club music through the sponsoring of a well-attended bingo game. During the Christmas seas on the College Court Sunday School gave a program in which the Glee Club was represented both financially and with musical contributions. Occasionally a soloist was provided by the club as an aid to programs elsewhere in the community.

Thus, we see that the College Court Glee Club had a very definite place in the housing project and in the community outside the project. 
A glee club, if well organized and made up of talented members, can be of real service to a community and is usually much in demand. This seemed to be true of the College Court Glee Club. According to the menager of College Court, the club did a "splendid job" for over a year. However, several of the members decided to attend evening school at the Municipal College for Negroes nearby, a program which utilized all of their spare time. Then one of the remaining members died and his wife was forced to move from the project. This brought about the termination of the Glee Club. The club was formally disorganized with a party at which gifts were distributed to each of the members. The Glee Club of College Court is now extinct and was so at the time this study was begun. However, such a previous organization was deemed worthy of mention.

The manager maintains, "There are other poople here on the project who desire to sing and we have had community singing of various kinds, but, as singing is an art, we find them inoapable of making representative showing and we have deferred reorganization of the Glee club until at same time we find other voices that can do oredit to the name." However, singing is not such an art that it cannot be cultirated in people who may not realize their innate qualities and capabilities. This cultivation required volunteer leadership of a most talented and cooperative sort, and such is not easy to bring about. It has been suggested thet College Court may find itself inhabited by a well-educated, higher inoome group which demands a more costly, sophisticated program of activities. This suggestion seems somewhat well founded as we progress further into our study. 
Ninety-six answers to the question, "Do you belong to ary clubs within College Court at present?" revealed only twenty-one answering "yes" against seventy-five answering "no". It may well be that coincidence did not include the "joiners" and activists in the answers. However, the phrase, "Faithful Few," seems to apply. There is in evidence in College Court a nucleus group of volunteer "leisure time organizers" who are the sponsors and workers in each activity and organization. This is not particularly to be condemned. Always in any leisure time activity or organization there are those who assume leadership and responsibility. This may be due to additional talent, additional eduoation and training, greater amount of leisure time, etc. It may be a wholesome situation provided that such leadership and assumed responsibility do not tend to daminate an entire program, thus discouraging any trend toward participation on the part of the many. In College Court such harmful domination on the part of a few tenants does not seem to be in evidence except in one or two cases.

Of the twenty-one residents stating that they were members of some organization within College Court at present, thirteen were members of the College Court Community Club (Men's Club), seven were members of the Women's Social Charity Club, four were members of the Recreation Council, three were interested in the sewing class, one was a member of the softball team (men's) and one listed the College Court Sunday School as her major interest. Duplication is somewhat in evidence. It has already been suggested that a good many of the more active residents belong to and partioipate in more than one or two of the organized groups. These groups will be discussed one by one. 


\section{Women's Social Charity Club}

The Women's Social Charity Club was organized June 13, 1938. Because of several deaths and illnesses during the spring of 1938, the project manager suggested to a group of women that it would be well to have an organization in the Court that would give some emergenoy relief and aid to those who are in distress either through death or illness and, at the seme time, form a social group that could entertain themselves with the facilities that the project had to offer. Thus the club was organized at the suggestion of the manager of the project with the purpose of doing charity work, such as cheering the sick with fruit and flowers, sending flowers to the decersed and giving financial aid to persons who are in noed in the court and in the community.

One of the present members and a former president of the club, though not the first president, was responsible for organizing the Women's Social Charity $C l u b$ and arranging for its first meetings. This particular individual was chosen by the manager as organizer because of her interest in charity work. In the beginning of the organizing procodure, the organizer visited those women in College Court who she thought would be most interested in the prospects of a Social Charity Club. She had no difficulty in "selling the idea" to those with whom she talked. This charter member seemed to believe that the majority of the nembers of the club are such beoause they naturally like and believe in charity work. They are not members merely because of the ontertainment afforded at social moetings.

The Women's club elected a president, a secretary, a treasurer, and a business manager. At present the secretary and treasurer are one. 
The original secretary and business manager are still holding office. The present president is the third to hold the position. The organization began with ten members and gredually increased to twenty-three members. The present membership is seventeen. The olub moets the first Tuesday evening in each month for the purpose of transacting business. A meeting on the third Tuesday evening of each month is set aside for the entertainment of the members. Visitors are occasionally invited to the entertainment meeting. Refreshments are served, paid for each meeting by the members. Games are played interspersed by an occasional dance program.

Regular business meetings of the Sociel Charity Club are not too well attended as far as members are concerned. The average attendance is approximately nine out of a mombership of seventoen. When visited, all the members appeared to be well known to all the other members and gave evidence of being good friends. All members appeared to be accepted by the group. The members of the group exhibited apparent congeniality. They cooperated and worked well together. Each member contributed toward the group purpose. There was a minimum of "bickering" and uncooperetive conduct.

The impetus, initiative and responsibility for the life of the Women's Club appeered to came from within the group itself, but not always from the entire membership. The very fact that many of the members were continually absent gives evidence thet not all the group are interested in giving impetus to group activities. While the whole group had opportunity for self-expression during the course of the meeting not every momber present participated in the discussion at hand. 
A few of the more active and responsible nembers did most of the talking. The members did give evidence of planning and carrying out their activities and facing issues which emerged from their experiences together. The mood of the Women's Social Charity Club during the course of a meeting was characterized by the play spirit and was marked by occasional laughter rather than by overly purposeful and serious attitudes. There was an absence of strain, anxiety and striving.

The members of the club concern themselves with their own needs and interests rather than those of a leader or the prescriptions of a nationally planned program. The activities planned at the business meetings gave evidence of having grown out of programs or projects previously experienced by the group and related also to larger projects anticipated for the future. In addition to its charitable funotions the Women's Club sponsors such activities as baby showers, baby contests, health lectures (e.g., a tuberculosis and heart lecture during the celebration of Negro Health Week, March 31 to April 7, 1940) and movies, cake raffles, a Gingham Dress Ball and bingo games. The group appears to be interested in most of the aotivities for the sake of the activity itself rather than in some extraneous awards or prizes, or points. Bingo games naturally would not be included in such a category. Bingo ganes are definitely money raising devices. Those participating in such do so with little thought to the pleasure derived therefrom, but with a great deal of though to the financial reward.

The meotings of the Social Charity Club are usually opened and closed with a prayer by one of the nembers. This is indication of the church and religious influence prevalent in College Court gatherings. 
Various statements from the members of the Women's Social Charity Club indicate the place of the club in the lives of these nembers. All of the members interviewed mantained that the club certainly aids in ostablishing friendships within College Court. The secretary of the club further stated that "we go into the home where there is sickness and meet and make friends with someone whom we have not met before." The educational value of such a club was also stressed by several members. "There's no other club giving both service and recreation," esserted one member. Another tenant emphasized the provision of inexpensive leisure time activity as one benefit derived from the Women's Social Charity Club.

Approximately half of the members interviewed stated that they would have belonged to such a club regardless of College Court residency. These interviewees have always been interested in various charitable and social organizations through their church work. One member went so far as to state that she could not live without membership in such a club. However, another half of the members interviewed maintained that it was due to residency in College Court that they belonged to such an organization as the Women's Social Charity Club.

The Women's Club is not lacking in proper relationship with the project itself. The business manager of the club stated that "the Social Charity Club is a valuable asset to the project. The Club receives full cooperation from the management, the manager visiting business meetings from time to time." Many of the women living in College Court would like to belong to the club but cannot do so because either they or their husbands work at night. This does not allow 
these potential members to attend meetings. The activities, both charitable and social, sponsored by the Women's Social Charity Club comand the respect of the entire project.

The Club functions to some extent outside the project. An exainple is service rendered to the Old Folks Home in the form of Christmas baskets. Outside visitors are invited to educational and health programs sponsored by the club. Community resources in persons, institutions or materials are used whenever possible.

It would be much more desirable and commendable if the Women's Club activities were oarried on by a larger number of women in College Court rather than remaining the responsibility of only a few comprising a nucleus group around whom the club functions. However, the reasons for this laok of widespread member ship have already been suggested.

\section{Recreation Council}

Within College Court there is an organization known as the Recreation Council. This was organized December 8 , 1938, with a president, secretary, and a treasurer. The purpose of the Council is to assist with the recreational supervisors (Work Projects Administration) in their entertainment of the children on the playgrounds; to sponsor entertainments whereby money can be raised to pay for refreshments and social entertainment for the children; and to help keep discipline on the playgrounds. According to the president of the Recreation Council, who is perhaps the best informed person in the project on matters of leisure time activities and club organizations, the idea for a recreation council originated with a person who was previously assigned to College 
Court as a worker by the City Department of Recreation. This young woman is no longer with the project, the city having discontinued activities in the recreation field within the housing projects at the end of the summer of 1938.

The Council started with about twenty-five members. There are now fifteen members on the Council, all of them in active service. Most of the nembers are mothers. The Recreation Council chooses as one of its necessary functions the raising of money for purposes of a Christmas fund and a recreation treasury. Proceeds from money-raising activities go jointly to these two funds. The recreation treasury is used for purchasing materials for the children.

The City Recreation Depertment worker was in the project such a short time that she was unable to organize the Council properly. Therefore the present chairman or president of the Council was designated as organizer. She selected people for the Council with whom she had the most influence. At first the Council members depended upon their president and organizer. When the Recreation Counoil was in its infency no suggestion came from the members. However, Council activities have gradually given the members more self-confidence. There are more human contacts now among the membership. Each individual possesses a sense of belonging to the group and a feeling of responsibility. Further, mare pleasures and greater value are obteined from various programs.

The membership of the Recreation Counoil at the present time inoludes the president of the Men's Club, the president and business manager of the Women's Social Charity Club, the wife of the resident 
manager of the project, and the wife of the superintendent of the college Court sunday School, together with the president of the Council itself and nine other members. The nine additional members are mostly mothers of children.

The Recreation Council meets the first and third Thursday evenings in each month. The members realize that their own children are a part of whatever plans are made for safer and more valuable recreation within College Court. This contributes to added interest and increased energy. It is true that such an inoentive is not an ideal one. But the Council includes members without children so that a more social viewpoint is also present. One member stated that, "the Recreation Council keeps the members active as well as the children in College Court and the outside neighborhood. Then too, the members get acquainted with the "higher ups'." By the "higher ups" this tenant meant the social worker for the projects and the Housing Commission officials.

There are definitely more activities in College Court due to the action of the Counoil. This increase in activities necessitates a planned schedule in order to prevent the various organizations from conflicting in regard to program meetings. Everything sponsored by the Recreation Council in the way of social functions and entertainment is given for the benefit of the College Court community at large. Few affairs are ever given merely for the enjoyment of the Council members. For special occasions visitors from outside are selected. Only friends in the neighborhood outside the project are invited to these special functions. 
The Council works with the management of the project in regard to any planned program given for the community at large. The manager, according to the members, has always been most cooperative. The majority of the programs are open to everyone, including the outside neighborhood. Health movies and lectures and other programs of an educational nature are becoming more numerous. The lectures and movies are free. The president of the Recreation Council asserts that "the tenants just wouldn't attend such things in their former neighborhoods." Various interviewres pointed out one factor as a contribution to full attendance at program gatherings, the fact that there is little necessity for "dressing up" or preparing in order to attend a program within the project. In former neighborhoods this need for "looking more presentable than usual" loomed as an item in decreasing interest. Two hundred and fifty to three hundred people present at the last Christmas entertainment and celebration sponsored by the Recreation Councjl is further evidence of the place of the Council in the project and in the surrounding community. This also may serve to indicate the need for the Christmas fund which the Recreation Council maintains.

\section{College Court Cormunity Club}

With the organization of various women's groups in College Court the men of the project felt that they had been left out of the picture. With the help of the W.P.A. male recreation leader in the project the men docided to form a hen's Social Night. Obteining such good results with the woekly meeting, it was not long thereafter that they agreed it would be a good idea to form a permanent organization. 
Thus the College Court Community Club (known to its members as the 4-C Club) or Men's Club was organized February 28, 1939. Its purpose is to furnish recreational facilities to the men of the court and community and to contribute finanoially and with remembrances when needed to members and neighbors. The club was organized as an outgrowth of a group of friends who, at various tinies, found themselves thrown together for ane reason or another. Upon enjoying each other's company, the idea of a olub took form.

Aocording to the president of the 4-C Club, Joe Louis was scheduled to fight Max Schmeling one night in the latter part of February, 1939. Several of the men in College Court planned to place a radio in the recreation room for the benefit of any men in the project who wished to listen to the fight that evening. This plan was carried out and quite a large number of would-be fight fans and Louis supporters turned out. At the conclusion of the Louis victory, the suggestion was made that a club be formed based on those in attendance that night at the radio fight program. The suggestion was mot with enthusiam and the club organized.

The 4-C Club started with only a few members and then grew rapidly. Due to a number in the club living outside the project and yet living in the immediate neighborhood, the club named itself the "College Court Community Club."

In the beginning it was thought advisable to charge an entrance feo of $\$ I$ in order to discourage "undesirables" from joining the club. This system, however, tended to bar some very desirable individuals. Therefore, the plan was abandoned and the foe reduced to $25 \phi^{\prime}$ 
The Men's Club elected a president, a secretary, and a treasurer. In the beginning there were many "backward" individuals who said little and depended upon a small, nucleus group in the club to take the initiative. This small group of leaders were those who were well read, especially in the field of current events, and rell adjusted socially and educationally. Thus, this "clique" endeavored to bear the responsibility for the club program until the majority of the members became accustomed to self-expression and cooperation.

The president of the College Court Community Club, a rather young man of social alertness and ability, revealed the fact that he sometimes resorts to personal contacts in creating interest in and support for a given suggestion, idea or program. Approaching various members before a meeting, he sees to it that they clearly understand an issue to be roted upon, and that they know how he stands on the subject. In fact, so thoroughly and pointedly do the president and two or three other officers and nembers express their own views that the majority of the members often have no pert in what should be a "group idea." The whole group, while having opportunity for selfexpression during the course of a meeting, often feels inadequate in making suggestions which are not in total agreement with or not consistent with those of the president, secretery, etc.

Several of the formerly active nombers have complained that the lien's Club has not developed as they originally had anticipated. They maintain that there is too much talk and coercion on the part of the president and a chosen few. One member asserted that elaborate plans were formulated at the first few meetings, but that little hes 
been done to develop these plans. It is true that during the course of the first year of the club's existence the membership had reached a peak of forty-one members. However, on the club's first birthday the membership totaled only nineteen. Of these nineteen only about half are really active and consistent in attendance. The inactive members merely pay dues in order to keep their status and membership in the club. The College Court Community Club meets the first and third Wednesday evenings of each month.

Along with this brief analysis we must realize that when the club was visited all the members appeared to be known to all the other members and gave evidence of being good friends. There was no uncooperstive conduct within the meeting. As has been suggested, howerer, the impetus, initiative and responsibility for the life of the group appeared to come from the president of the group rather than from the group itself.

The question of a permanent meeting place was an early one. The men found that the project's recreation room was not sufficient to assure them privacy and regularity of meetings. With the cooperation of the management, the members succeeded in furnishing a basenent storeroom into a convenient and comfortable meeting place. This clubroom has been improved gredully, leisure time equipment in the form of table games and reading material being added from time to time. The room is available at all times for recreational purposes and informal gatherings. Several of the men would rather frequent the clubroom then leave the premises of College Court for movies, dances and similar activities. This is one indication of what a program 
of this sort can mean to the members of such an organization.

One aspiration of the fien's Club is the provision of a club library. At present there are a few books which have been contributed by members, but no shelvas for their care. Many subscribers to various periodicals of current interest bring these periodicals to the clubroam for a magazine exchange system. In this way it is hoped that a few non-readers will become interested in subjects of current appeal.

One function of the College Court Cominity Club is the maintenance of a limited charity program, sometimes in cooperation with the Women's Social Charity Club. The men seek to aid their sick or otherwise unfortunate comrades. The president of the club mantains that there has never been any dissension concerning a program of that sort.

For Negro Health Feek, 1940, the Men's Club sponsored a lecture, "Anti-Syphilis," by Dr. Rowntree, Assistant Health Director for the City of Louisville.

A Recreation Committee of the Men's Club was appointed in the spring of 1939 by the president of the club. This wes and is a very vital and necessary committee, according to the president. Men's softball within the project was the activity which first made the comrittee necessary. The purchasing of equipment and reconmendations for programs are the responsibilities of this reoreation committee of chosen men. The president of the "4-C" Club reveals that the comittee was carefully selected according to influence, interest, and ability. 


\section{Men's Softball}

Men's softball began as a team ohosen from the College Court Community Club. It mas organized on Jume 28, 1939, with a manager and a captain. Softball activities grew to such proportions that the men's softball organization became a separate group aside from the Men's Club. During the summer of 1939 the tean was composed of eighteen members. After playing together for a short while the members of the team deoided to join the City Recreation Department's softball league. According to the manager of the team, even though it plays in competition, the primary purpose of the team is to furnish recreation to its members. While softball team members are not obligated to belong to the Men's Club, the club, through its recreation camittee, retains partial responsibility for the team. As has been mentionod, the purchasing of equipment is the function of the "4-C" Club and its committee. The president of the College Court Community Club emphasized that the club is careful not to allow softball to dominate its activities or control the treasury. However, two members complained that the club is not run on a business-like basis. Money is taken at random from the treasury by the club officers. There is often little opportunity to vote on expenditures. The members are told about the expenditures at the next meeting. These individuals further stated that a large part of the money went for softbell equipment used by only a part of the membership. Perhaps such was true during a particular phase of the club's development. Further interviewing found other members confident that, in regard to generel expenditures, the members of the Men's Club are beginning to realize the significance and value of providing results 
of a permanent nature for the project. That is, the club with its money strives to make a lasting, beneficial imprint in College Court rather than to waste money in a frivolous manner.

Since its organization the College Court Comunity Club has sponsored several bingo perties. The club has chosen this means as the best way to raise money. There is no doubt that a successful bingo game is a good money-raising verture. But there is again the same criticism, that the group is not interested in the activity for its own sake but rather for some extreneous reward. Further, the frequency and popularity of bingo parties in College Court supports the suggestion that a higher income group demands a more costly program of activities. The "4-C" Club means a great deal to the members who do take an active and responsible part in its activities. One member stated that in his opinion there "is no equal to the '4-C' Club. I probably would be a member of same such club if not a resident of college court, but it would not be as good a club. The residents of College Court are all of good character so that the olub itself is of good quality." "The Men's Club cen't be beat," asserts another member. "We'd never see each other if it were not for the club. It keeps the men inside College Court for their recreation and they don't care to leave the premises." A third resident.maintained thet "half the mombers in the Men's club don't want men in the club who live outside the project.

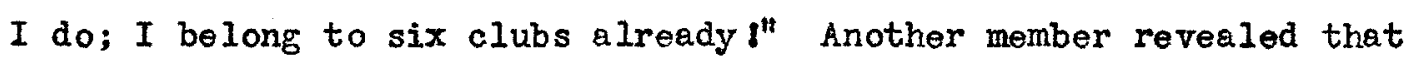
the club "helps one to learn the order of business procedure in meetings. I learn to speak and to express myself. I don't always agreo with club policy. The Men's Club means union in College Court. It 
means fellowship. Those residents who can't attend the meetings ask Ebout the club."

The president of the College Court Community Club emphasized the possibilities for the success of such a club within a housing project. In regard to a clubroom there is no rent, hent or light to be maintained. Outside the project this would not be the ocse. The president praised the project manager's cooperative spirit. The manager is an honorary member of the club. "We don't know what we'd do here at College Court without him," asserted the "4-C" Club's president, referring to the resident manager.

\section{Kollege Kourt Juniors}

On February 3, 1939, another club, the Kollege Kourt Juniors, was organized at the home of one of the members. The club consists of ten girls, nine of whom are residents of College Court. The secretary of the club lives outside the project. She ras allowed to join because of her interest and ability. It is not the general policy of the club to admit outsiders to membership, but such is the case when the outside candidate is deemed worthy by the resident members.

Originally the age limit for membership in the K. K. Juniors, as they call themselves, was restriated to 17 and 18 years. However, there were not enough girls of that age available in College Court. Therefore, the age limit was lowered to 15 years, thus attracting ten $\operatorname{gir} 18$.

A glee club was the originel purpose for organizing the K. K. Juniors. This idea developed into the organization of a service club. 
Two or three girls desired to form a club and they approached those they assumed would be interested. The membership in the club is limited to ten members. However, this rule is not too rigid. If an additional girl sought nembership and was well accepted by the present members, she would probably be adnitted. There are really no other girls of this age living in College Court.

The charter nembers of the club had some difficulty in organizing. They requested one of the women residents in the project to aid them in the organization process. This resident has remained with the K. K. Juniors as club advisor. She suggests programs and aids in the business procedure.

The officers of the Kollege Kourt Juniors consist of a president, a vice-president, secretary, a treasurer, an historian, and chairman for two comittees. Thus almost every member of the club has some responsibility.

The K. K. Juniors meet the second and fourth Friday nights in each month. The second Friday evening is deroted to business, and the fourth is reserved for social activities. The president of the club asserted thet the charity and service program of the group is similar to that of the Women's Social Charity Club. Social functions often include boys invited by the girls. At one time it was suggested that boys be included in the membership, but this plan was not adopted. Oocasionally the girls met in the sooial roon of College Court for their social programs. The adjoining kitchen is then used and refreshments are served. The girls take pleasure in dancing either with boys or among themselves. 
The president of the K. K. Juniors maintains that there is very little quarreling among the members, although occasionally some disagreement arises. She described the olub as "something to look forward to and something of meaning to the members." Several of the members stated that they had never belonged to a "worth-while" club until they mored into College court.

\section{Tallyho Bricge Club}

The Tallyho Bridge Club is another spontaneously organized club of some seven women of College Court. The olub originated at the suggestion of one of the members. Two of the members, one of them the president of the club, live outside college court. The club is composed of younger marrled women. This group of young women were never interested In the Tomen's Social Charity Club. In fact, there is almost a marked degree of competition and rivalry evident within the Tallyho Bridge Club in regard to the older Women's Club. The secretary of the Bridge Club explained that "cur club is planning some serviee work outside College court in the future, this in addition to our bridge. Te feel that such service will make us an even stronger cluh than the Tomen's Social Chority Club."

The secretary of the Tallyho Bridge Club emnhasized that the olub is independent of College Court. She asserted that all members would belong to such a club whether residents of the project or not. The Tallyho Bridge Club is typical of most bridge clubs. The members were rather intim te friends before the formation of the club. There is little doubt that they would have organized for bricge in any neigh- 
hood or situation just as many such bridge olubs have organized. Meetings of the Tallyho Bridge Club are held at the various apartments of the members every other Thursday afternon. The meeting begins at 2 P.M. and adjourns at about 5:30 P.Y. A discussion of club business, the serving of refreshments and bridge playing ompose the program for an afternoon. Visitors at meetings are not desired by the members. Most of them are somewhat timid and would foel suppressed by the presence of a visitor. The manager of the project was at one time denied his request to visit during a meeting.

\section{Sunday School}

In May, 1038, the project manager suggested to some of the older tenants in College Court that an interdenominational Sunday School be or anized, stressing no particular denomination. It was organized June 10, 1938, with superintendent, a secretary, and a treasurer. The attendance arerages from fifteen to twenty persons each Sunday. One College Court resident, the superintendent of the Sundsy school, is responsible for the adults present and another for the young people.

The College Court Sunday School was able to purchase literature and song books. During the month of December in 1938 a Christmes program was sponsored by the Sunday School and approximately one hundred and ten children of Col lege court and vicinity were presented with gifts. As has boen mentioned elsewhere, a similar program was sponsored in 1939 in connection with the various clubs.

In March, 1939, the Sunday School gave a silver tea. Negro churches throughout the city sent representatives. 
Fgg hunts at Faster are sponsored for the children of the ommunity at large by the Sunday Sohool and the Recrestion Council.

On July 23,1939 , the College Court Community Sunday School sponsored its first carnital under the leadership of the chaiman of the Recreation Council, who is also chairman of the entertainment committee of the sunday school. Aocording to the superintendent of the Sunday school, the residents of college court and the community at large gave their hearty support to the carnival.

\section{Boy seout Troop}

Troop 76, Boy Scouts of America, was formed in the late fall of 1938. The young men of college court are very much interested in this troop. The scouts have on several occasions raised funds for their membership foes. They have pooled their interests in such a way that when one scout cannot pay his fee, the others pay it for him. The less fortunate scout must, of course, pay back at a later date. The scout troop did not receive its charter from the National Counc1l unt 11 April, 1939.

The scoutmaster of the College Court scout troop is not a resident of the project. Several of the members also live in the community outside college court. The troop meets each Tednesday evening. Approximately twenty members compose the membership of the troop.

Aside from the clubs and activities organized by the management and the tenants themselves, college court was aided in its recreational program for a time by the city Recreation Department. This ald began In May, 1938, in the form of a full-time staff member. This worker 
outlined a recreational program which embraced the following activities: singing games, folk daneing, story telling, handicraft, short hikes and outings, drama, puppetry, clay modeling, handball, female calisthenies and other social games. These activities were regularly scheduled and met at certain periods each week. A nuppet speoialist of the City Recreation Department $\nabla$ isited the playground during the summer of 1938 with his puppets. The e frequent risits were an incentive to the young people of college Court in making puppets and presenting shows for themselves.

Eventually College Court was deprived of the services of the City Recreation Department. This change was due to a reduction in the budget of that partieular department. However, the demand was so great for a recreational leader in College Court that the project hes been

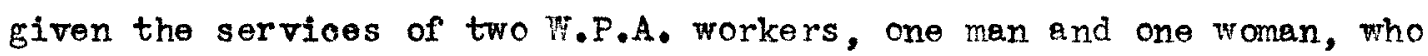
carry out scme of the activities begun by their predecessor.

At the present time in College Court the weekly schedule of activities is somewhat as follows: The pre-school age youngsters are provided for each morning frcm 9 A.M. to 12 nocn. On Tuesday and Thursday afternocns twelve or thirteen girls, ares 6 years to 10 years, meet for weaving and singing games. On Monday and Wednesday afternoons frcm 2 P.M. to 4 P.M. two sewing classes, each with a membership of about eight women, meet together. These classes were formerly very actively engeged in weaving rugs. Such activity resulted in the formation of a "rug club" which has now developed into two rather talented sewing classes. On Tuesday evening ladies' ping-pong is in evidence in the recreation room from 6 to 8 P.M. About fifteen to 
twenty adults are occupied with social dancing each Thursday evening from 7 P.M. to about 9:30 P.M. On Friday night at 8 o'clock about fifteen adults met for folk danoing until around 9:30 P.M.

A great deal of the above leisure time program is subject to change from month to month. The pre-school age activities are usually quite regular as far as schedule is concerned. But the remaining activities are dependent upon the desires of the participants. Perhaps the interested individuels decide to meet at another period due to working hours, etc., or perhaps interest lags in one activity and is inoreased in another. Thus there is a continuous chang in a flexible schedule and in program activities themselves. These ohanges refer only to W.P.A.-sponsored recreational activities and not to the organized clubs and groups in the project.

It must be pointed out here that the W.F.A. workers receive a great deal of aid from College Court residents in providing an open recreation program. Pre-school age children are often oared for by the mothers in the project. A minimum amount of folk danoing is handled by the chairman of the Recreation Council. The same person is also responsible for the formation of a Junior Glee Club consisting of members from 5 to 10 years of age. This group meets in the afternom, although it has not been meeting on definite schedule for several months. The chaiman of the Recreation Couneil oonducts and instructs the group. It may be added that this Recreation council chaiman is seemingly the "mainstay" of recreational programs and group organization in College Court. The philosophy of "key poople" is often justifiably subject to oriticism, but here is one "key person" without whom college 
Court would suffer where recreation is concerned.

Forty-two residents out of ninety-six answering the question, "Do you participate in any recreational activities offered in the recreation room?" indicated that they did. The remaining fifty-four were interested in movies and church organizations predominantly. sixty-six out of ninety-six residents stated that they would like to have more space indoors available in College court for clubrooms, recreation rooms, ete. It is significant to note that twenty-four of those tenants who went on record as not participating in recreation room activities stated thet they would like more space for such. This may infer that a larger, better equipped social and recreation room would attract more participants. Perhaps those not frequenting the recreation room refrain from dcing so due to overerowded conditions when the room is occupied.

Leisure time activities in college court definitely reach their maximum during the summer months. Playground facilities outof-doors serve an entire community. Playground participation is regulated so as not to inconvenience Col lege court residents. Overcrowing is sometimes reduced by limiting the number of outside participants seeking playground facilities.

Out of ninety-six residents only four stated that they were in any way disturbed by children playing on the play space within College Court. Fifty-one out of the same number of tenants stated that they would like to have more outdoor space for play within College court.

One mother living in the project maintained that "the ohildren 
learn to play together under supervised recreation in college court. If it were not for supervised recreation, the children would just run wild." Another mother commented on the relation between play spece for children and better health conditions in the family. She seemed certain that residence in college court was responsible for improved health.

The chairman of the Recreation Council of College Court revealed a rather significant factor in the total leisure time situation. Sho maintained that there is a defintte class distinction within College Court which sometimes operates at soolal gatherings. Tenants belonging to different eccnomis levels and cultural backgrounds tend to "band together" within these scoial barriers.

Arbitrarily, the chief oriteria for differenoes in social class among Negroes in Louisville are based on family background, apparent economic status, education, cocupation and regard for the mores. To these objective criteria must be adied the attitudes of superiority or inferiority which are held by the members of various groups toward other groups. Color enters in subtle ways. For the most part and except in private conversation, color prejudice is unvoiced. There are very few clearly differentiated cliques which may be suspected of olor consciousness. There are no churches to which dark Negroes are not welcomed as members. However, it has been obsprved that an exelusive fraternity danoe is "Iighter in color" than a "pay" dance or even an invitational club dance.

Group Iife and leisure time activities within College Court cannot be completely discussed without further mention of the part played by the resident manager of the project. It has already been 
mentioned that any project manager must occupy a place in the lives of the residents. Also sme indication has been given of the place the manager fills in College Court's every day life. After weeks of searching for talented people in the early stages of colloge Court's development, it was then his task to recognize those capable of leadership. Aocording to the manager, "this was a delicate job, for if you err in selecting leaders, it will dismpt a once started program and will retard group progress."

The manager summarizes his organizational techniques and difficulties by maintaining, "I find that there is no better group of my people to work with than the College Court group. Fuman nature is the same everywhere, and you will find in various groups those who love and understand the work, those who have the capacity to work and will work voluntarily, those who love the work but are inoapable of leadership, and those who are capable but have a deficiency known as petty jealousy. However, results can be obtained if the sponsor can work with and overlook these deficiencies."

The project manager further states that what little success and cooperation he has had in College Court has been largely due to the fact that the tenants he ve been constantly instructed as to the philosophy of the United States Housing Act. 
CONCLUS IONS 


\section{CONCLUS IONS}

The foregoing social interpretation of college Court hes been an attempt to show the effect of publio housing on group iffe and leisure time activities. This much at least can be said for soolel, recreational, and educational activities in connection with housing; they have definitely taken root.

The general possibilities regarding commuity life in housing projects are not too definite, but they are present. Community iffe as such may be impossible in an urban environment. One's friends are likely to live in widely scattered parts of the city, and they constitute one's real community. Mere physical nearness of sleoping quarters can scarcely oonstitute a satisfactory basis for joint activities. It does not appear to be the case that people who buy houses in the same locality have the same tastes, desires and backgrounds. However, the residents of a housing project are Iiving together in a development that represents an idealistic venture. That ideal may serve to stimulate a sense of community "belonging." We have seen that College Court residents, as much as possible, are beoming familiar with the philosophy of the Inited States Housing Act. This tends to prompt a community spirit within the project. Housing projeot tenants naturally have approximately the same incomes. Similarity in income does not stimulate group iffo or promote comnunity spirit. Income does not determine taste, desire, or background. Similarity in former living conditions is often based on 
sinilarity in income. Like income, it does not influence oomunity life in the housing project.

In College Ccurt wo do find a tenant group with similar oocupational status. Since most of the College Court residents are domestics, they possess a feeling of "brotherhood" for the nelghbors who are engaged in the same type work. Similarity in occupation seems to make community life nore possible.

The housing developments throughout the country are new ventures. College court is still relatively new even though it is more than two years old at the time of this writing. People do not spontaneously organize into a community within a larger urban environment. They must be edveated to such a concept. This implies time and leadership. Regarding community life, there is a marked simllarity between the housing projeot and the neighborhood settlement. The manager of the project may be looked upon as a head worker attempting to organize the ommunity and establish a pattem of group activities. Leading residents who act as volunteer group leaders may be compared to the worker employed by or the volunteer offering service to the settlement house. Such a comparison reveals the possibilities of com unity life within the housing project.

The Negro residents of College Court have responded to the community Iffe and group life spirit in a rather satisfactory way. Yet we cannot say thet group life in college court includes the majority of the residents. Nor can we say that the existing groups are ideal. We oan only emphasize that there is in the projeot a definite program around which further activity may be organized. 
It is maintained that Negroes take readily to organized social activities. They are supposed to be natura]. "joiners." In College court this has not proved true of the majority. It is true that several of the residents are quite social in their approach. But these several do not constitute the residents of college court. An innate religious attitude and a feeling for "charity work" are responsible for much of the success of group organization in College court. This fact does not altogether decrease the value of such organization. It is merely responsible for most of the groups in College Court being motivated rather than voluntary.

The motivated group is that in which the membership may be voluntary, but influenced by extemal conditions. The individual is won over to motivated groups because he likes an activity or thinks he will like it. The need for group approval, the collective tendencies, and the social needs of the individual also play a part in a rousing interest in such groups. Thus, members participate in their activities more cheerfully and more responsively than they do in the forced group, and are likely to gain more than they would from the latter, where merbership is almost compulsory. They would not gain as much, however, as they would from a purely voluntary group.

Under good leadership and with a sound group work practice a motivated group can become eduoationally $\nabla \theta$ luable. This occurs when the content of the program, the methods employed in introducing activities, learning and skills, and, above all, the relations botween the leader and the members resemble those of the voluntary group, which at+racts its membership benause it satisfies some inner craving that may 
be externally or subjectively motivated, but that represents a true interest.

We see, then, that a few of the motivated clubs and groups in College Court, the Women's Social Charity Club, the College Court Community Club, the Recreation Council, the Boy scout Troop and several other leisure time groups may develop into valuable organizations, even more so then they are at present. A most effective means of porsonality development is participation in the l1fe of the larger community. As the group grows older, the members must be made aware of the strivings of the community, the nation, and the world toward solving their problems and for improvement of 11fe. Group work fails in Its inission if it fails to develop in people a sense of social responsibility and a desire to participate actively, each in his own way, in world improvement. In College Court we have observed the various clubs and groups. We have revealed the fact that leisure time activities do exist. Wo have not, however, seen any indication of interest in the soolal problems with which the Negro is faced. This interest, it would seem, should be in evidence among Negro tenants living together in a housing project. True the resident manager of the project is interested in such problems. But we see no social action groups composed of the residents themselves. This may well be due to the fact that college Court residents are not too concermed with the problems of their race as a whole, since they themselves are from a higher income group. This does not imply that College court residents are not oonfronted with problems of rece barriers and race prejudices. The may merely infer that perhaps the members of a self-satisfled group are not always 
ready to spend their leisure disoussing and taking action in regard to the social problems which more seriously affect those who are less fortunate.

The absence of any grlevance comittee in College court is not particularly surprising. Col lege Court is small. One hundred and twenty-five apartments do not constitute a major maintenance problem. The complaints are such thet they can be met on an individual basis. The resident manager of the project is cooperative to the extent that all grievances are adequately handled, and thus there is little need for the formation of such a committea. Further, the majority of the tenants may be so well satisfied with their present situation that any suggestion of a grievance committee would be rather unpopular.

The size of College Court may have its effect on the resronse to a community spirit and group life. A small projeot allows for a more intimate, "face-to-face" relationship among tenants. That is, one tenant can more easily beome acquainted with all the other tenants in a sinall project. There is fust a short distance from one side of the project to the other. This is true in college court. Several of the social leaders in the project are acquainted with at least the majority of the residents. This makes for a sense of "belonging" and community life as far as these few tenants are concemed. However, the remaining residents do not experience this same feeling. They haven't taken the trouble to "make friends" with everybody in the project. It is left to the initiative of the resident as to whether he will take advantage of the project being small, and "make friends." Large housing projects would tend to heve more activities and 
organlzations due to the fect that the re would be a greater number of residents. Out of this greater number oome more individuals interested in social activities who are prepared to aot as rolunteers. Naturally, the more people, the more chance for organized groups. The proportion of interested residents may not be any greater than that in a small project. College Court is a small projeot, and the number of volunteer leaders from among the residents may have reached its maximum. There is still possibility, however, of increasing the number of group partiolpants in College court. This depends again on the attitude of volunteer leadership and program ontent.

College court's oontribution to the neighborhood and communty outside of its own boundaries is mostly in the way of inadequate facilities for recreation which the outside neighborhood oan make use of, and some religlously motivated charity work. Unless a commity spirit as such within a housing projeot is coordinated with a sense of sooial responsibility for the larger community outside the project, that commity spirit is not one moving toward social progress. The group spirit in the projeot may tend to revert in upon itself rather than move out to the larger community. However, the commity and group spirit hos not dereloped in college Court to such an extent that it reacts in either way. Many individuals in the projeot are still not group conscious, project onscious, or socially consolous.

Leedership is definitely needed in every housing project. Group life within the projeot is dependent largely upon the leadership available. The groups do not seem to develop from the residents themselves merely because they live in close proximity. The group organization 
that exists in College Court has been the result of leadership and not due just to the fact that the group members live in college court. However, it must be admitted that these groups can be more easily organized within a housing project where the residents are easily available to the group leaders, and where the residents do heve something in common in the way of occupation, and occasionally, iterls. The cooperation between the management and the residents may. be very close and highly satisfactory or the opposite may be true. In College court the relationship is close. The importance of a harmonlous constructive attitude on the part of both the management and the residents is obvious. There is no doubt that lack of eoperation or tendency toward antagonism on the part of the person who is responsible for the management of the housing development spells many diffioulties for healthy growth of community life. The question of selecting qualified personnel for conducting housing developments is essential. The training of this personnel must not only include knowledge of building management and of housing problems but also the knowledge of social problems and possibilities of their solution. In 2.11 housing devolopments where social ectivities are expected to flourish the people who are in charge must have a sccial point of view.

Volunteer residents in the projeot should not be labeled as "key people." It is true that they are residents with influence, personality, and ability. But can they not be used as rolunteer leaders in the same way that leaders living outside the projeot would be used? These leading residents have the same status as the volunteer worker in the settlement house. In College court the volunteer residents 
ere seen as Chairman of the Recreation Council, President of the Men's Club, President of the Tomen's Club, advisor to the Kollege Kourt Juniors, and Superintendent of the Sunday School. The conflict arises when these volunteer leaders with ability, in turn, begin to select their own "key people" within their ow group, forgetting the importance of group action and the group idea.

The leader guides the group and is at the same time himself guided by the group, is always a part of the group. No one oan truly lead except from within. One danger of conceiving the leader as outside is that then what ought to be group loyalty will become personal loyalty. When we hate a leader within the group these two loyalties merge. It might be well at this point to present a sumnary of the basic physical requirements, as exemplified by College court, for carrying on an adoquate social activities program. These considerations are obviously minimal.

of the errors and omissions in project plans, the lack of a large auditorium is the most serious. Some other detalls can be added after the building is presumably completed, but not a meeting hall or a gymnasium. The auditorium should be large enough to accomndate mass meetings, lecture audiences, parties, dances, and even a theatrical audience. It ought to be oquipped with a stage and plenty of lights. Free play space, for both children and adults, is essential not only outdoors but indoors. All space allotted for social activities should be much larger than anyone not experienced in the field is likely to believe necessary. New noeds arise constantly, and no one can possibly foresee every type of facility that may be required. Most of the 
individual rooms should be suitable for use in more than one activity. In a word, the whole plan should be highly adaptable to ohanging needs. Due to lack of fecllities within a project, many residents look to outside commercial recreation. This obviously tends to hinder any development of group and community spirit.

What is it that a person seeks when he joins a group or a club? A number of motives suggest themselves. The need of affection, group aoceptance and recognition, sctivity, security, friendship, admiration, a sense of belonging and communiostion. It is, therefore, necessary to create conditions and relations in the family, group and club where these noeds may be satisfled.

Residents in College court who are members of groups or elubs are beginning to benefit by their participation. There are numerous adults and young people who lack the essential patterns of behavior in a group relation. They do not possess elementary cultural tools for group life. Group experience with a purpose and whole-hearted interest is perhaps the most certain method of reaching such individuals, for they learn by experience rather than through abstract teaching. The group must therefore supply face-to-face contacts in an informal relation, where the conflicts, hostilities, friendships, and cooperation can occur and find expression. Personality is modifled through interaction and first hand experiences.

Group members in College Court are learning to express themselves before the group, are making new friendships, and are learning to plan activities cooperatively. While those receiving group experience are in the minority numerically, they, at least, are examples of what 
such experience might mean to all the residents of a project.

In College court those who actively participate in group activities are the ones who take pride and interest and responsibility in the project venture in which they live. Group Iifo produces a marked change in attitude of the tenant toward the new environment. Far from deteriorating the value of the property, the tenants working through the group have heen steadily and intelligently enhanoing its value.

The fundamental reason for emphasizing the value of group life is that no one can give us democracy; we must learn democracy. To be democratically inclined is not to decide on a certain form of human association. It is to learn how to live with other men. There is in man the spirit of mutuel aid as well as the combative, competitive spirit. It is to this spirit that the pioneers of public housing appea1. 
BIBLIOGRAPHY 


\section{BIBLIOGRAPHY}

\section{Books}

Aronovici, Carol. Housing the Masses. New York: John Wiley \& Sons, 1939.

Bauer, Catherine. Modern Housing. New York: Houghton Mifflin Co., 1934.

Busch, Henry. Leadership in Group Work. New York: Association Press, 1934.

Coyle, Grace. Studies in Group Behavior. New York: Harper \& Brothers, 1937.

Dewey, John. Democracy and Education. New York: Macmillan Co., 1916.

Follett, Mary. The New State. Now York: Longmans, Green \& Co., 1926.

Fisher, E. M., and Ratcliff, R. U. European Housing Policy and Practice. Wa shington: U.S. Federal Housing Adninistration, 1936.

Goldfeld, Abraham. Diary of a Housing Manager. Chicago: National Association of Housing Officials, 1938.

Hogben, Lancelot T. Retreat from Reason. New York: Random House, 1938.

Hutton, J.E. Welfare and Housing. New York: Longmans, Green \& Co., 1918.

Jacks, L. P. The Education of the Whole Man. New York: Harper \& Brothers, 1931.

Jacks, L. P. Education Through Recreation. New York: Harper \& Brothers, 1932 .

Hardy, C. O. Housing Prograrn of the City of Vienna. Washington: Brookings Institution, 1934 .

Lieberman, Joshua. New Trends in Group Work. New York: Assooiation Press, 1938.

Lindenberg, Sidney. Supervision in Group Work. New York: Association Press, 1939. 
Books (continued)

National Association of Housing Officials. Housing Year Book. 1938 and 1939 .

Neumeyer, M. H. Leisure and Recreation. New York: A. S. Barnes \& Co., 1936.

Perry, C. A. Housing for the Hachine Age. New York: Russell Sage Foundation, 1939 .

Pink, I. H. The New Day in Housing. New York: John Day Co., 1928.

Post, I. W. The Challenge of Housing. New York: Farrer \& Rinehart Co., 1938.

Powdermaker, Hortense. After Freedom. New York: The Viking Press, 1939.

Rowlands, D. T., and Woodbury, C. Current Developments in Housing. Philadelphia: American Academy of Political and Social Scienoo, 1937.

Slarson, S. R. Creative Group Eduartion. New York: Association Press, 1937.

Steiner, J.F. Americans At Play. New York: MoGraw-Hill Co., 1933.

Straus, M. W., and Wegg, T. Housing Comes of Age. New York: Oxford University Press, 1938.

United States Federal Emergenoy Administration of Public Works. Urban Housing. Washington: 1936 .

Veiller, L. T. Housing Situation and the Way Out. National Housing Association, 1920 .

Veiller, L. T. Model Housing Law. New York: Russell Sage Foundation, 1920.

Wood, Edith E. Housing of the Unskilled Wage Earner. New York: Macmillan Co., 1919.

Wood, Edith E. Recent Trends in American Housing. New York: Macnillan Co., 193 I.

Work Projects Administration. Leisure Time Leadership. Washington:

U. S. Government Printing Office, 1938 . 


\section{Pamphlets and Roports}

Alfred, Helen L. Municipal Housing. League for Industrial Democracy, 1932 .

American Program of Low Rent Public Housing. Washington: U. S. Federal Administration of Public Works, 1935.

Boyd, Neva L. Social Group Work, A Definition With a Hethodological Note. Chicago: Northwestern University, April, 1937.

Causal Factors in Infant Mortality. Publication No. 142, U. S. Children's Bureau, 1925.

Children of Pre-school Age in Gary, Indiana. U. S. Children's Bureau, Washington, 1922 .

Goldfeld, Abraham. Toward Fuller Living Through Public Housing and Leisure Time Activities. New York: National Public Housing Conference, 1934 .

Health Calendar. Health Council of Louisville, April, 1940.

Homes for Workers. Washington: U. S. Federal Emergency Administration of Public Works, 1937.

MoDonald, Stewart. Achievenents of the Federal Housing Administration. Wa shington: U.S. Federal Housing Administration, 1936.

National Housing Act. (As Amended). Washington: U. S. Federal Housing Administration, 1939.

Negro Housing Problen in Louisville. Louisville City Planning and Zoning Comission, 1932.

New York Crine Conmission. Report, 1930.

Play Spece in New Neighborhoods. New York: National Recreation Association, 1939 .

Real Property Inventory of 1934. City Planning and Zoning Commission, Louisville, $\mathrm{Ky}$.

Real Property Survey and Low Income Housing Survey of Louisville, Ky. 1938-39, Work Projects Administration, City of Louisville Municipal Housing Commission, and City Planning and Zoning Commission.

Simkhovitoh, Mary K. The Settlement Primer. National Federation of Settlements, 1936 . 


\section{Pamphlets and Reports (continued)}

The Tenement House Commission of Louisville. Report, February 16, 1909.

Williamsburg Houses. Wrshington: U. S. Federal Housing Administration, 1937 .

Wilson, Elizabeth A. "Recreation in Louisville--An Historical Sketch." Unpublished Master's Thesis, Departnent of Sociology, University of Louisville, 1938 . 